\title{
Article
}

\section{Hydroethanolic Extract of Prunus domestica L.: Metabolite Profiling and In Vitro Modulation of Molecular Mechanisms Associated to Cardiometabolic Diseases}

\author{
Hammad Ullah ${ }^{1,+}+\mathbb{D}$, Eduardo Sommella ${ }^{2,+}$, Cristina Santarcangelo ${ }^{1,+} \mathbb{D}$, Danilo D'Avino ${ }^{1}$, Antonietta Rossi ${ }^{1}$, \\ Marco Dacrema ${ }^{1}$, Alessandro Di Minno ${ }^{1,3}{ }^{\mathbb{D}}$, Giacomo Di Matteo ${ }^{4} \mathbb{D}$, Luisa Mannina ${ }^{4}$, Pietro Campiglia ${ }^{2,5} \mathbb{D}$, \\ Paolo Magni ${ }^{6,7, *(D)}$ and Maria Daglia $1,8, *$ (D)
}

check for updates

Citation: Ullah, H.; Sommella, E.; Santarcangelo, C.; D'Avino, D.; Rossi, A.; Dacrema, M.; Minno, A.D.; Di Matteo, G.; Mannina, L.; Campiglia, P.; et al. Hydroethanolic Extract of Prunus domestica L.: Metabolite Profiling and In Vitro Modulation of Molecular Mechanisms Associated to Cardiometabolic Diseases. Nutrients 2022, 14, 340. https://doi.org/ $10.3390 /$ nu14020340

Academic Editors: Flávio Reis and Winston Craig

Received: 2 December 2021

Accepted: 10 January 2022

Published: 14 January 2022

Publisher's Note: MDPI stays neutral with regard to jurisdictional claims in published maps and institutional affiliations.

Copyright: (c) 2022 by the authors Licensee MDPI, Basel, Switzerland. This article is an open access article distributed under the terms and conditions of the Creative Commons Attribution (CC BY) license (https:// creativecommons.org/licenses/by/ $4.0 /)$.
1 Department of Pharmacy, University of Napoli Federico II, Via D. Montesano 49, 80131 Naples, NA, Italy; hammad.ullah@unina.it (H.U.); cristina.santarcangelo@unina.it (C.S.); dani.davino@studenti.unina.it (D.D.); antrossi@unina.it (A.R.); marco.dacrema@unina.it (M.D.); alessandro.diminno@unina.it (A.D.M.)

2 Department of Pharmacy, University of Salerno, 84084 Fisciano, SA, Italy; esommella@unisa.it (E.S.); pcampiglia@unisa.it (P.C.)

3 CEINGE-Biotecnologie Avanzate, Via Gaetano Salvatore 486, 80145 Naples, NA, Italy

4 Department of Chemistry and Technology of Drugs, Sapienza University of Rome, Piazzale Aldo Moro 5, 00185 Rome, RM, Italy; giacomo.dimatteo@uniroma1.it (G.D.M.); luisa.mannina@uniroma1.it (L.M.)

5 European Biomedical Research Institute of Salerno, Via De Renzi 50, 84125 Salerno, SA, Italy

6 Department of Pharmacological and Biomolecular Sciences, Università degli Studi di Milano, 20133 Milan, MI, Italy

7 IRCCS MultiMedica, Sesto San Giovanni, 20099 Milan, MI, Italy

8 International Research Center for Food Nutrition and Safety, Jiangsu University, Zhenjiang 212013, China

* Correspondence: paolo.magni@unimi.it (P.M.); maria.daglia@unina.it (M.D.)

+ These three authors share the first authorship.

\begin{abstract}
High consumption of fruit and vegetables has an inverse association with cardiometabolic risk factors. This study aimed to chemically characterize the hydroethanolic extract of P. domestica subsp. syriaca fruit pulp and evaluate its inhibitory activity against metabolic enzymes and production of proinflammatory mediators. Ultra-high-performance liquid chromatography highresolution mass spectrometry(UHPLC-HRMS) analysis showed the presence of hydroxycinnamic acids, flavanols, and glycoside flavonols, while nuclear magnetic resonance(NMR) analysis showed, among saccharides, an abundant presence of glucose. P. domestica fruit extract inhibited $\alpha$-amylase, $\alpha$-glucosidase, pancreatic lipase, and HMG CoA reductase enzyme activities, with IC50 values of $7.01 \mathrm{mg} / \mathrm{mL}, 6.4 \mathrm{mg} / \mathrm{mL}, 6.0 \mathrm{mg} / \mathrm{mL}$, and $2.5 \mathrm{mg} / \mathrm{mL}$, respectively. P. domestica fruit extract inhibited lipopolysaccharide-induced production of nitrite, interleukin- $\beta$ and PGE 2 in activated J774 macrophages. The findings of the present study indicate that $P$. domestica fruit extracts positively modulate in vitro a series of molecular mechanisms involved in the pathophysiology of cardiometabolic diseases. Further research is necessary to better characterize these properties and their potential application for human health.
\end{abstract}

Keywords: Prunus domestica L.; chemical characterization; digestive enzyme inhibition; HMG-CoA reductase inhibition; anti-inflammatory activity

\section{Introduction}

The metabolic syndrome (MS), (also called as "Reaven's syndrome", "Syndrome $\mathrm{X}^{\prime}$, "Insulin resistance syndrome", and "the deadly quartet") [1-3], is a cluster of pathological conditions including visceral obesity, hyperglycemia, or type 2 diabetes mellitus (T2DM), hypertension, and dyslipidemia, and is associated with higher cardiovascular disease (CVD) risk. A prolonged and persistent condition of MS may indeed silently progress towards serious complications such as T2DM, when not yet present, coronary heart disease (CHD), heart failure, stroke, cerebrovascular accidents (CVA) and stroke, as 
well as liver complications (nonalcoholic fatty liver disease (NAFLD) and nonalcoholic steatohepatitis (NASH)) [4,5]. Adipose tissue dysfunction is commonly associated with MS, and dysregulated secretion of pro- or anti-inflammatory adipokines may contribute towards MS-induced complications [6,7]. Indeed, elevation of circulating tumor necrosis factor-alpha (TNF- $\alpha$ ), interleukin-6 (IL-6), and C-reactive protein (CRP) are predominantly observed in patients with dysregulated metabolism $[8,9]$.

Increasing age, sedentary lifestyle, female gender, lower socioeconomic class, positive family history, excessive alcohol intake, unhealthy dietary patterns, and intake of numerous medications are some of the risk factors associated with the prevalence of MS [10,11]. In this context, prevention is essential. Adopting a healthy lifestyle, aimed at weight normalization, increasing physical activity and adoption of a healthy diet, including increased intake of fruits, vegetables, and whole grains and a low consumption of salt, trans fatty acids, and cholesterol-rich foods [12]. However, as maintaining a healthy lifestyle on a daily basis is challenging, specific pharmacological interventions (i.e., statins, reninangiotensin-aldosterone system (RAAS) inhibitors, and insulin-sensitizing agents, etc.) are often prescribed to target some selected pathogenetic mechanisms [12-14]. The main limitations of the pharmacological approach are the increase in the occurrence of adverse and side effects without beneficial effects on low-grade inflammation [15]. In this context, there is a growing attention to food supplements able to decrease the modifiable risk factors of MS [16]. One of the most widely used food supplement ingredients is red yeast rice (RYR), made by fermentation of rice with Monascus purpureus, producing monacolin K, which, in lactone form, is identical to lovastatin. RYR is used alone or in combination with plant extracts, coenzyme Q10, chromium, and vitamins. In 2018, the Panel on Food Additives and Nutrient Sources added to Food of the European Food Safety Authority (EFSA) has expressed doubts about the actual safety of RYR and concluded that EFSA is "unable to identify a dietary intake of monacolins from RYR that does not give rise to concerns about harmful effects to health" [17]. Besides RYR, other natural compounds could be effective strategies in the treatment of MS and prevention of MS progression towards serious complications through the inhibitory activity of the enzymes associated with carbohydrate/lipid digestion and cardiometabolic diseases (i.e., $\alpha$-amylase, $\alpha$-glucosidase, HMG-CoA reductase, and pancreatic lipase) [18-20].

Research analysis has shown an inverse association of increased consumption of fruits and vegetables with the incidence of MS risk factors [21,22], though there is a strong need to identify the specific effects of fruits and vegetables on the risk of MS development [23]. Prunus domestica L. (European plum) is known for its health benefits, which may be the result of its antioxidant potential and anti-inflammatory effects [24,25]. Plums are fruits with low glycemic index, thus their consumption in adequate amount and on a regular basis could be a potential preventive strategy against MS [25,26]. In addition, plums are commonly consumed when on a diet, they are commercially available at low cost, and as happens for many fruits, some of the plums produced are discarded as they do not reach the size requirements to be placed on the market.

As finding new food supplement ingredients which are safe and effective in the prevention of MS is an unmet need, especially after the concern of EFSA regarding RYR, the present study aimed to (1) characterize the metabolite profile of a hydroethanolic extract of Prunus domestica, using a multimethodological approach that was previously used for the study of different food matrices $[27,28]$, and two analytical techniques, untargeted nuclear magnetic resonance (NMR) spectroscopy and targeted ultra-high-performance liquid chromatography high-resolution mass spectrometry (UHPLC-HRMS), and (2) study the in vitro modulatory effects of this extract on the activity of a panel of enzymes differentially involved in the pathophysiology of MS and the modulation of proinflammatory mediator release. 


\section{Materials and Methods}

\subsection{Preparation of Fruit Extracts}

Two different varieties of Prunus domestica L. fruits (P. domestica L. subsp. domestica, also known as common plum, and P. domestica L. subsp. syriaca, also known as Mirabelle plum) (Figure 1) were collected from a local cultivator in the Campania Region (Italy) in October 2020. Eight fruits were sampled for each variety (Common Plum and Mirabelle Plum). All fruits were first washed with water to eliminate every dirt residue and were separated into skin and pulp. Both parts were cut into small pieces with a ceramic knife. To control oxidation during preparation, the samples were cut in an ice bath. The samples were freeze-dried and then ground into fine powder using a mortar and pestle. Aliquots of 1 and $2 \mathrm{~g}$ of the powdered skin and pulp were added to $20 \mathrm{~mL}$ and $40 \mathrm{~mL}$ of $50 \%, 70 \%$ and $99 \%$ ethanolic solution acidified with $0.1 \%$ HCL solution, respectively. The sample pH values were adjusted to 2.0 , and the samples were subjected to magnetic stirring for $3 \mathrm{~h}$ at room temperature, followed by centrifugation at $6000 \mathrm{rpm}$ for $10 \mathrm{~min}$. The precipitate was separated from the supernatant. The same procedure was repeated three times and the supernatants of each sample were collected and filtered through Whatman cellulose filter paper. The filtrate was concentrated in a rotary evaporator at a temperature lower than $30{ }^{\circ} \mathrm{C}$ and submitted to freeze drying. The dry extracts were kept at $-20{ }^{\circ} \mathrm{C}$ for subsequent determination of total polyphenol content, antioxidant activity, untargeted NMR spectroscopy, and targeted UHPLC-HRMS.

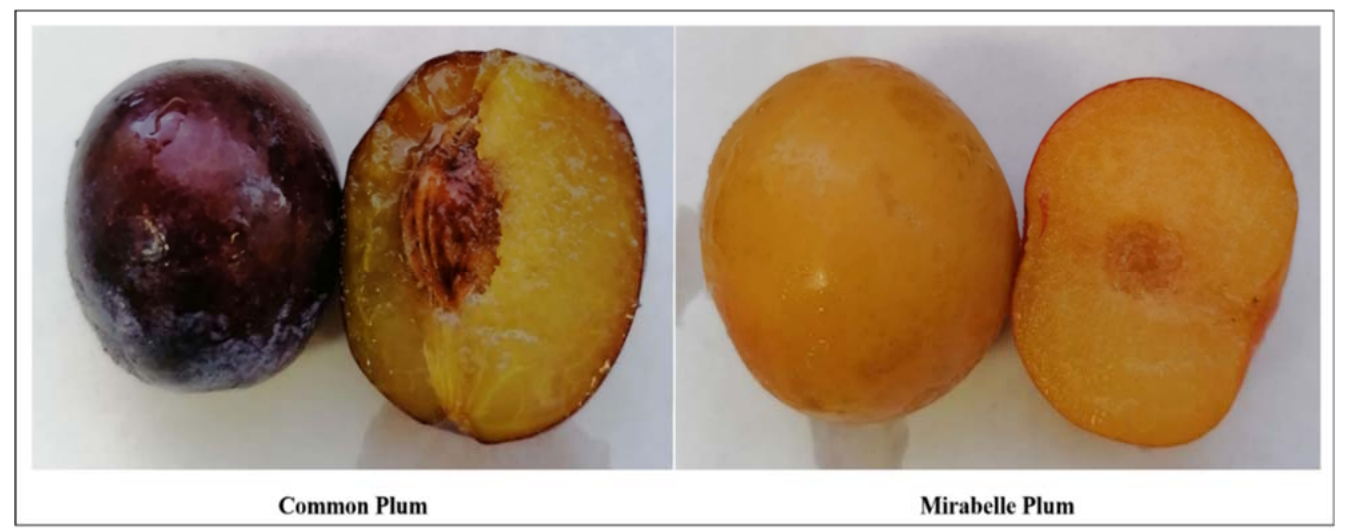

Figure 1. Plum varieties, collected from a local cultivator in the Campania Region (Italy). P. domestica L. subsp. domestica (Common plum) and P. domestica L. subsp. syriaca (Mirabelle plum).

Based on the assessment of total polyphenol content and antioxidant activity, the fruit pulp extract of $P$. domestica subsp. syriaca obtained with $50 \%$ hydroethanolic solution was selected, and in view of the high content of glucose and sucrose determined via NMR, it was subjected to the chemical precipitation of its sugars by treatment with absolute ethanol, followed by an ultra-freezing temperature. The organic solvent was removed under reduced pressure by a rotary evaporator and the dry extract obtained from the fruit pulp extract of $P$. domestica subsp. syriaca without sugars was kept at $-20^{\circ} \mathrm{C}$ for subsequent biological assays.

\subsection{Total Phenolic Contents}

Total phenolic content (TPC) was determined using a colorimetric assay (FolinCiocalteu method), following the same protocol as set by Singleton et al. with some modifications [29]. An aliquot $(10 \mu \mathrm{L})$ of the samples $(50 \mathrm{mg} / \mathrm{mL})$ or gallic acid standard solutions $(200-1000 \mu \mathrm{g} / \mathrm{mL})$ was taken and added to $50 \mu \mathrm{L}$ of Folin-Ciocalteu reagent. The solutions were cyclomixed for $4 \mathrm{~min}$ and added to $200 \mu \mathrm{L} \mathrm{Na}_{2} \mathrm{CO}_{3}$ (15\%). The final volume was made to $1 \mathrm{~mL}$ with distilled water and allowed to incubate for $2 \mathrm{~h}$ at room temperature and under dark conditions. The solutions were read spectrophotometrically at $750 \mathrm{~nm}$. Gallic acid was used as standard compound, with serial dilutions being prepared with 
known concentrations ranging from 200 to $1000 \mu \mathrm{g} / \mathrm{mL}$. The results were expressed as $\mathrm{mg}$ equivalent to gallic acid/g of extract on dry weight basis.

\subsection{Antioxidant Assay}

ABTS (2,2'-azino-bis3-ethylbenzthiazoline-6- sulfonic) assay was performed to evaluate the antioxidant potential of the fruit extracts following protocols set by Kok et al. with slight modifications [30]. The assay was conducted by placing $1 \mathrm{~mL}$ ABTS solution in a microtube, to which $10 \mu \mathrm{L}$ of sample $(50 \mathrm{mg} / \mathrm{mL})$ or Trolox $(0,15,20,25,30$ and $35 \mu \mathrm{M})$ was added. The mixture was allowed to incubate for $2.5 \mathrm{~min}$, and the absorbance was read at $734 \mathrm{~nm}$. Thus, the antioxidant compounds present in the fruit extracts quench the color and produce a decoloration of the solution which is proportional to their antioxidant activity. The results were expressed as Trolox equivalent concentration $(\mu \mathrm{M} / \mathrm{g}$ of extract on dry weight basis).

\subsection{Metabolic Profiling of P. domestica Fruit Pulp Extract}

The metabolic profiling of $P$. domestica fruit pulp extract was evaluated using UHPLCHRMS and NMR analysis.

\subsubsection{RP-UHPLC-HRMS Analysis}

P. domestica fruit pulp extract was solubilized in methanol/water (50:50 v/v). The sample was then filtered through a cellulose acetate/cellulose nitrate mixed esters membrane ( $0.45 \mu \mathrm{m}$; Millipore Corporation, Billerica, MA, USA), and analyzed by RP-UHPLC-HRMS. UHPLC-HRMS analysis was performed on a Shimadzu Nexera UHPLC system, consisting of a CBM-20A controller, two LC-30AD dual-plunger parallel-flow pumps, a DGU-20 AR5 degasser, an SPD-M20A photo diode array detector (PDA), a CTO-20A column oven, and a SIL-30AC autosampler. The system was coupled online to a hybrid Ion trap Time of Flight Mass spectrometer (LCMS-IT-TOF, Shimadzu, Duisburg, F.R. Germany) equipped with an electrospray source (ESI). For RP-UHPLC analysis, a Kinetex Biphenyl $100 \mathrm{~mm} \times 2.1 \mathrm{~mm}$, $2.6 \mu \mathrm{m}\left(\mathrm{L} \times\right.$ I.D, particle size, Phenomenex ${ }^{\circledR}$, Bologna, Italy) column was employed at a flow rate of $0.4 \mathrm{~mL} / \mathrm{min}$. The mobile phases consisted of (A) $0.1 \% \mathrm{CH}_{3} \mathrm{COOH}$ in $\mathrm{H}_{2} \mathrm{O}$ and (B) ACN plus $0.1 \% \mathrm{CH}_{3} \mathrm{COOH}$. Analysis was performed in gradient as follows: 0-20.0 min, 2-20\% B; 20.01-22.0 min, 20.01-99\% B; 99\% B hold for $1 \mathrm{~min}$; returning to initial conditions in $0.1 \mathrm{~min}$. The column oven was set to $40^{\circ} \mathrm{C}$ and $5 \mu \mathrm{L}$ sample was injected. PDA detection parameters were sampling rate $12 \mathrm{~Hz}$, time constant $0.160 \mathrm{~s}$ and chromatograms were extracted at 280 and $330 \mathrm{~nm}$. LC data elaboration was performed by the LCMS solution ${ }^{\circledR}$ software (Version 3.50.346, Shimadzu, Duisburg, F.R. Germany). MS detection was performed in negative mode ionization as follows: curve desolvation line (CDL), $250{ }^{\circ} \mathrm{C}$; Block Heater, $250^{\circ} \mathrm{C}$; Nebulizing and Drying gas, 1.5 and $10 \mathrm{~L} / \mathrm{min}$; ESI ${ }^{-}$Capillary Voltage, $-3.5 \mathrm{kV}$; MS range, $\mathrm{m} / \mathrm{z}$ 150-1500; ion accumulation time, $30 \mathrm{~ms}$; ion trap repeat, 3. MS/MS was performed in a data-dependent acquisition (DDA), precursor ions selection was based on the base peak chromatogram (BPC) intensity of 700,000. Collision-induced dissociation (CID), 50\%, ion trap repeat. For analysis, the instrument was tuned using sodium trifluoroacetate (NaTFA). Metabolite annotation was based on accurate mass measurement, MS/MS fragmentation pattern and comparison within silico spectra with MS database searching [31,32]. "Formula Predictor" software (Shimadzu, Duisburg, F.R. Germany) was used for the prediction of the molecular formula using the following settings: maximum deviation from mass accuracy: $5 \mathrm{ppm}$, fragment ion information, and nitrogen rule.

\subsubsection{NMR Analysis}

P. domestica fruit pulp extract (500 $\mathrm{mg}$ ) was solubilized in $10 \mathrm{~mL}$ of $400 \mathrm{mM}$ phosphate buffer/D2O containing 3-(trimethylsilyl)-propionic-2,2,3,3-d4 acid sodium salt (TSPA), used as internal standard for quantitative measurements, and EDTA, used as a complexing agent for metal ions. Then, an aliquot of $0.7 \mathrm{~mL}$ was transferred in a $5 \mathrm{~mm}$ NMR tube. The NMR spectra were recorded at $25^{\circ} \mathrm{C}$ on a JNM-ECZ 600R (JEOL Ltd., Tokyo, Japan) spectrometer 
operating at the proton frequency of $600.17 \mathrm{MHz}$ equipped with an autosampler and the SuperCOOL cryogenic probe (JEOL Ltd., Tokyo, Japan). The ${ }^{1} \mathrm{H}$ spectrum was acquired using a presaturation pulse sequence to suppress water signal, a $90^{\circ}$ pulse of $12.8 \mu \mathrm{s}$ and $65 \mathrm{~K}$ data points. All the NMR spectra were processed using the JEOL Delta v5.3.1. software (JEOL Ltd., Tokyo, Japan). The ${ }^{1} \mathrm{H}$ spectrum after Fourier transformation was manually phased, automatically base-corrected and referred to the $\beta$-glucose $\mathrm{CH}-1$ signal set at $4.66 \mathrm{ppm}$. 2D NMR experiments, namely ${ }^{1} \mathrm{H}-{ }^{1} \mathrm{H}$ COSY, ${ }^{1} \mathrm{H}-{ }^{1} \mathrm{H}$ TOCSY, ${ }^{1} \mathrm{H}-{ }^{13} \mathrm{C}$ HSQC and ${ }^{1} \mathrm{H}-13 \mathrm{C} \mathrm{HMBC}$, were performed using the following experimental conditions: ${ }^{1} \mathrm{H}-{ }^{1} \mathrm{H}$ COSY and ${ }^{1} \mathrm{H}^{1} \mathrm{H}$ TOCSY experiments were carried out with water presaturation during relaxation delay and $9 \mathrm{kHz}$ of spectral width in both dimensions. ${ }^{1} \mathrm{H}-{ }^{1} \mathrm{H}$ COSY was acquired using $4 \mathrm{k} \times 256$ points in F1 and F2, respectively, a relaxation delay of $2.5 \mathrm{~s}$ and 44 scans, whereas in the case of ${ }^{1} \mathrm{H}-{ }^{1} \mathrm{H}$ TOCSY experiment, $8 \mathrm{k} \times 256$ points in $\mathrm{F} 1$ and F2 dimensions, respectively, a mixing time of $80 \mathrm{~ms}$, a relaxation delay of $2 \mathrm{~s}$ and 52 scans were used. ${ }^{1} \mathrm{H}-{ }^{13} \mathrm{C}$ HSQC experiment was carried out using a $90^{\circ}{ }^{1} \mathrm{H}$ pulse of $12.8 \mu$ s and $90^{\circ}{ }^{13} \mathrm{C}$ pulse of $14.0 \mu \mathrm{s}$, a spectral width of $9 \mathrm{kHz}$ and $33 \mathrm{kHz}$ for the ${ }^{1} \mathrm{H}$ and ${ }^{13} \mathrm{C}$ dimensions, respectively, $8 \mathrm{k} \times 256$ points, a relaxation delay of $2 \mathrm{~s}, 80$ scans and a coupling constant $1 \mathrm{JC}-\mathrm{H}$ of $150 \mathrm{~Hz} .{ }^{13} \mathrm{C}$ spectra were referenced to the $\mathrm{CH}-1$ resonance of $\beta$-glucose at $97.00 \mathrm{ppm} .{ }^{1} \mathrm{H}-13 \mathrm{C} \mathrm{HMBC}$ experiment was carried out with $12.8 \mu$ for ${ }^{1} \mathrm{H}$ and $14.0 \mu$ s for ${ }^{13} \mathrm{C} 90^{\circ}$ pulse, a spectral width of $9 \mathrm{kHz}$ and $38 \mathrm{kHz}$ for the ${ }^{1} \mathrm{H}$ and ${ }^{13} \mathrm{C}$ dimensions, respectively, $8 \mathrm{k} \times 256$ points in F1 and F2 dimensions, a relaxation delay of $2 \mathrm{~s}$, a delay for the evolution of long-range couplings of $50 \mathrm{~ms}$ and 76 scans. In order to quantify the assigned compounds, the integral of the corresponding selected ${ }^{1} \mathrm{H}$ resonances were measured with respect to the integral of TSP methyl group signal normalized to 100. Quantitative results were expressed in $\mu \mathrm{g} / \mathrm{mg}$ of dry weight.

\subsection{Enzyme Inhibition Assays}

Inhibition assays of different enzymes associated with the MS were performed as described below. The selected fruit extract ( $P$. domestica subsp. syriaca fruit pulp), dissolved in 1\% DMSO (SERVA Electrophoresis $\mathrm{GmbH}$, Aurogene, Rome, Italy) and respective positive controls were tested using different concentrations to obtain half minimal inhibitory concentration $\left(\mathrm{IC}_{50}\right)$ for each enzyme, by nonlinear regression analysis. The absorbance of the sample blank (buffer in place of enzyme solution) and control (buffer in place of extract) was recorded as well. The inhibition of enzyme activity was calculated using following equation:

$$
\% \text { inhibition }=\left[\left(\mathrm{A}_{\text {control }}-\mathrm{A}_{\text {extract }}\right) / \mathrm{A}_{\text {control }}\right] \times 100
$$

\subsection{1. $\alpha$-Amylase Inhibition Assay}

The $\alpha$-amylase from porcine pancreas inhibition assay was performed according to the protocol set up by Cicolari et al. with slight modifications [33]. The reaction mixture contained $20 \mu \mathrm{L}$ fruit extract solution (concentration range: $0.0625-25 \mathrm{mg} / \mathrm{mL}$ ) or acarbose (concentration range: $15.56-400 \mu \mathrm{g} / \mathrm{mL}$ ), and $20 \mu \mathrm{L}$ enzyme solution $(0.5 \mathrm{mg} / \mathrm{mL})$ in $0.02 \mathrm{M}$ sodium phosphate buffer ( $\mathrm{pH} 6.9$ with $0.006 \mathrm{M} \mathrm{NaCl}$ ), which was preincubated for $10 \mathrm{~min}$ at $25^{\circ} \mathrm{C}$. Then, $20 \mu \mathrm{L}$ of $1 \%$ starch solution was added to each tube at timed intervals and allowed to incubate for $10 \mathrm{~min}$ at $25^{\circ} \mathrm{C}$. The reaction was stopped by the addition of $40 \mu \mathrm{L}$ color reagent (DNSA). The test tubes were incubated in a boiling water bath for $10 \mathrm{~min}$, and then cooled to room temperature. Finally, $600 \mu \mathrm{L}$ of bidistilled water was added to dilute the reaction mixture and the absorbance was read at $540 \mathrm{~nm}$ using a microplate reader.

\subsection{2. $\alpha$-Glucosidase Inhibition Assay}

The $\alpha$-glucosidase from Saccharomyces cerevisiae inhibition assay was performed according to the protocols set by Cicolari et al. with slight modifications [33]. The reaction mixture containing $50 \mu \mathrm{L}$ fruit extract solution (concentration range: $0.0313-25 \mathrm{mg} / \mathrm{mL}$ ) or acarbose (concentration range: $15.56-900 \mu \mathrm{g} / \mathrm{mL}$ ), and $100 \mu \mathrm{L}$ enzyme solution $(1 \mathrm{unit} / \mathrm{mL})$ in $0.1 \mathrm{M}$ phosphate buffer ( $\mathrm{pH}$ 6.9), was incubated in a 96 -well plate for $10 \mathrm{~min}$ at $25^{\circ} \mathrm{C}$. 
After preincubation, $50 \mu \mathrm{L}$ of $0.1 \mathrm{M}$ phosphate buffer ( $\mathrm{pH}$ 6.9) solution containing $5 \mathrm{mM}$ p-nitrophenyl- $\alpha$-D-glucopyranoside was added to each well at timed intervals, and was incubated for $5 \mathrm{~min}$ at $25^{\circ} \mathrm{C}$. The absorbance was read at $405 \mathrm{~nm}$ using a microplate reader.

\subsubsection{HMG-CoA Reductase Inhibition Assay}

The assay was conducted according to the manufacturer's protocol (Sigma-Aldrich). The assay was conducted by placing $910 \mu \mathrm{L}$ phosphate buffer with $5 \mu \mathrm{L}$ fruit extract (concentration range: $0.0625-30 \mathrm{mg} / \mathrm{mL}$ ) or $5 \mu \mathrm{L}$ pravastatin (concentration range: $18.75-300 \mu \mathrm{M}$ ) into microtubes; $20 \mu \mathrm{L}$ of NADPH and $60 \mu \mathrm{L}$ of HMG-CoA reductase substrate were then added. The analysis was initiated (time 0 ) by the addition of $5 \mu \mathrm{L}$ of HMG-CoA reductase, and incubated at $37^{\circ} \mathrm{C}$. The rate of NADPH consumed was monitored every $15 \mathrm{~s}$ for up to $5 \mathrm{~min}$ by reading the decrease in absorbance at $340 \mathrm{~nm}$, using the microplate reader.

\subsubsection{Pancreatic Lipase Inhibition Assay}

Porcine Pancreatic Lipase (PPL) inhibition assay was conducted according to the protocols reported by Nwakiban et al. (2019) [34]. The assay was conducted by mixing $30 \mu \mathrm{L}$ PPL $(2.5 \mathrm{mg} / \mathrm{mL}$ in $10 \mathrm{mM}$ MOPS and $1 \mathrm{mM}$ EDTA, pH 6.8) with $850 \mu \mathrm{L}$ Tris buffer (100 mM Tris- $\mathrm{HCl}$ and $5 \mathrm{mM} \mathrm{CaCl2}, \mathrm{pH} 7.0)$. Then, either $100 \mu \mathrm{L}$ of fruit extract (concentration range: $1.30-12.5 \mathrm{mg} / \mathrm{mL}$ ) or orlistat (concentration range: $1-500 \mu \mathrm{g} / \mathrm{mL}$ ) was added to the mixture and incubated for at $37^{\circ} \mathrm{C}$ for $15 \mathrm{~min}$, followed by the addition of $10 \mu \mathrm{L}$ substrate $(10 \mathrm{mM}$ p-NPB in dimethyl formamide). The mixtures were incubated again at $37^{\circ} \mathrm{C}$ for $30 \mathrm{~min}$. The absorbance was read at $405 \mathrm{~nm}$ using a microplate reader, to determine the lipase activity by quantifying the hydrolysis of p-NPB to p-nitrophenol.

\subsection{Cell Culture}

Murine monocyte/macrophage J774 cell line was obtained from the American Type Culture Collection (ATTC TIB 67). The cell line was grown in adhesion in Dulbecco's modified Eagles medium (DMEM) supplemented with glutamine ( $2 \mathrm{mM}$, Aurogene Rome, Italy) Hepes ( $25 \mathrm{mM}$, Aurogene Rome, Italy) penicillin (100 U/mL, Aurogene Rome, Italy), streptomycin $(100 \mu \mathrm{g} / \mathrm{mL}$, Aurogene Rome, Italy), fetal bovine serum (FBS, 10\%, Aurogene Rome, Italy) and sodium pyruvate (1.2\%, Aurogene Rome, Italy) (DMEM completed). The cells were plated at a density of $\sim 1 \times 10^{6}$ cells in $75 \mathrm{~cm}^{2}$ culture flasks and maintained at $37{ }^{\circ} \mathrm{C}$ under $5 \% \mathrm{CO}_{2}$ in a humidified incubator until $90 \%$ confluence. The culture medium was changed every 2 days. Before a confluent monolayer appeared, sub-culturing cell process was carried out. $P$. domestica subsp. syriaca fruit pulp extract was solubilized in DMSO at the concentration of $200 \mathrm{mg} / \mathrm{mL}$ (stock solution). Then, it was diluted in DMSO to obtain solutions at the concentrations of $150 \mathrm{mg} / \mathrm{mL}, 100 \mathrm{mg} / \mathrm{mL}, 20 \mathrm{mg} / \mathrm{mL}$ and $2 \mathrm{mg} / \mathrm{mL}$. Cells were plated to a seeding density of $5.0 \times 10^{5}$ in 24 multiwell plates. After $2 \mathrm{~h}$ of adhesion, cells were pretreated (for $2 \mathrm{~h}$ ) with increasing concentration of $P$. domestica subsp. syriaca fruit pulp extract ( $5 \mu \mathrm{L}$ of 2, 20, 100, 150 and $200 \mathrm{mg} / \mathrm{mL}$, which correspond to a final concentration in the well $(1 \mathrm{~mL})$ of $0.01,0.1,0.5,0.75$ and $1 \mathrm{mg} / \mathrm{mL})$. After the preincubation, macrophages were stimulated with or without LPS from Escherichia coli, Serotype 0111:B4, $(10 \mu \mathrm{g} / \mathrm{mL} ; 100 \mu \mathrm{L}$ of solution $100 \mu \mathrm{g} / \mathrm{mL}$ in DMEM completed with FBS, Sigma Aldrich, Milan, Italy) for $24 \mathrm{~h}$ [35].

\subsubsection{Nitrite, IL-1 $\beta$ and PGE 2 Assay}

After $24 \mathrm{~h}$ of incubation, the supernatants were collected for the nitrite, IL-1 $\beta$ and $\mathrm{PGE}_{2}$ measurement. The nitrite concentration in the samples was measured by the Griess reaction, by adding $100 \mu \mathrm{L}$ of Griess reagent ( $0.1 \%$ naphthylethylenediamide dihydrochloride in $\mathrm{H}_{2} \mathrm{O}$ and $1 \%$ sulphanilamide in $5 \%$ concentrated $\mathrm{H}_{2} \mathrm{PO}_{4}$; vol. 1:1; Sigma Aldrich, Milan, Italy) to $100 \mu \mathrm{L}$ samples. The optical density at $540 \mathrm{~nm}\left(\mathrm{OD}_{540}\right)$ was measured immediately after Griess reagent addition, using ELISA microplate reader (Thermo Scientific, Multiskan GO, Milan Italy). Nitrite concentration was calculated by comparison with $\mathrm{OD}_{540}$ of standard solutions of sodium nitrite prepared in culture medium. IL-1 $\beta$ (R\&D 
Systems, Aurogene, Rome, Italy) and $\mathrm{PGE}_{2}$ (Cayman Chemical, BertinPharma, Montigny Le Bretonneux, France) levels were measured with commercially available ELISA kits according to the manufacturer's instructions.

\subsubsection{Cell Viability}

Cell respiration, an indicator of cell viability, was assessed by the mitochondrialdependent reduction of 3-(4,5-dimethylthiazol-2-yl)-2,5-diphenyltetrazolium bromide (MTT; Sigma Aldrich, Milan, Italy) to formazan. Cells were plated to a seeding density of $1.0 \times 10^{5}$ in 96 multiwell plates. After stimulation with LPS in the absence or presence of test compounds for $24 \mathrm{~h}$, cells were incubated in 96-well plates with MTT $(0.2 \mathrm{mg} / \mathrm{mL})$, for $1 \mathrm{~h}$. Culture medium was removed by aspiration and the cells were lysed in DMSO $(0.1 \mathrm{~mL})$. The extent of reduction of MTT to formazan within cells was quantified by the measurement of $\mathrm{OD}_{550}$.

\subsection{Statistical Analysis}

Results from at least three independent experiments carried out in triplicate for TPC and antioxidant assay, and two independent experiments carried out in duplicate for enzyme inhibitory activities of the $P$. domestica fruit extract, were expressed as mean $( \pm S D)$ values. Student's t-test was used to determine the level of significance and statistical differences among variables using GraphPad prism. For the in vitro anti-inflammatory studies, the results were expressed as mean \pm standard error (SEM) of the mean of $n$ observations, where $n$ represents the number of experiments performed in different days. Triplicate wells were used for the various treatment conditions. The results were analyzed by one-way ANOVA followed by a Bonferroni post hoc test for multiple comparisons. A $p$-value less than 0.05 was considered significant. All graphs were generated using GraphPad prism, version 5 (GraphPad, San Diego, CA, USA).

\section{Results}

\subsection{Description of P. domestica Extracts}

Two different varieties of Prunus domestica L. fruits (P. domestica subsp. domestica and $P$. domestica subsp. syriaca), which were separated into pulp and skin, were submitted to three different hydroethanolic extractions to evaluate the effects of ethanol percentage in the extraction solvent on the total polyphenol content and antioxidant activity. The extraction yield calculated for the freeze-dried fruit skin ranged from 37 to $43 \%$ regardless of the Prunus variety. On the contrary, the extraction yield calculated for the freeze-dried fruit pulp ranged from 59.5 to $67 \%$ and from 45 to $49 \%$, for subsp. domestica and subsp. syriaca, respectively (Table 1 ).

Table 1. Fruit samples and yield of extracts.

\begin{tabular}{|c|c|c|c|c|c|c|}
\hline $\begin{array}{l}\text { Prunus } \\
\text { Variety }\end{array}$ & $\begin{array}{l}\text { Common } \\
\text { Name }\end{array}$ & $\begin{array}{l}\text { Skin } \\
\text { Color }\end{array}$ & $\begin{array}{l}\text { Fruit Part } \\
\text { Extracted }\end{array}$ & $\begin{array}{c}\text { Ethanol } \\
(\%)\end{array}$ & $\begin{array}{c}\text { Dry Extract } \\
(\mathrm{g} / \mathrm{g})^{1}\end{array}$ & $\begin{array}{l}\text { Extraction } \\
\text { Yield (\%) }\end{array}$ \\
\hline \multirow{6}{*}{$\begin{array}{c}\text { P. domestica } \\
\text { subsp. } \\
\text { domestica }\end{array}$} & \multirow{6}{*}{$\begin{array}{l}\text { Common } \\
\text { plum }\end{array}$} & \multirow{6}{*}{ Purple } & \multirow{3}{*}{ Skin } & 99 & 0.42 & 42.0 \\
\hline & & & & 70 & 0.39 & 39.0 \\
\hline & & & & 50 & 0.38 & 38.0 \\
\hline & & & \multirow{3}{*}{ Pulp } & 99 & 0.60 & 59.5 \\
\hline & & & & 70 & 0.63 & 63.0 \\
\hline & & & & 50 & 0.67 & 67.0 \\
\hline \multirow{6}{*}{$\begin{array}{l}\text { P. domestica } \\
\text { subsp. } \\
\text { syriaca }\end{array}$} & \multirow{6}{*}{$\begin{array}{l}\text { Mirabelle } \\
\text { plum }\end{array}$} & \multirow{6}{*}{ Yellow } & \multirow{3}{*}{ Skin } & 99 & 0.37 & 37.0 \\
\hline & & & & 70 & 0.41 & 41.0 \\
\hline & & & & 50 & 0.43 & 43.0 \\
\hline & & & \multirow{3}{*}{ Pulp } & 99 & 0.45 & 45.0 \\
\hline & & & & 70 & 0.46 & 46.0 \\
\hline & & & & 50 & 0.49 & 49.0 \\
\hline
\end{tabular}

1 The weight of dry extract obtained in grams per gram of sample used for extraction. 


\subsection{Total Phenolic Contents and In Vitro Antioxidant Activity}

A total of 12 hydroethanolic extracts were evaluated for their total phenolic content (TPC) and in vitro antioxidant activity (Table 2). The pulp of $P$. domestica subsp. syriaca extracted with $50 \%$ ethanol showed the highest TPC (12.9 mg GAE/g on dry weight basis), followed by fruit skin of $P$. domestica L. subsp. domestica extracted with $70 \%$ ethanol containing $12.8 \mathrm{mg} \mathrm{GAE} / \mathrm{g}$ on dry weight basis. Overall, the fruit extracts extracted with $99 \%$ of ethanol exhibited relatively less phenolics, with fruit pulp of P. domestica subsp. syriaca showing the lowest content of total phenolics ( $6.5 \mathrm{mg} \mathrm{GAE} / \mathrm{g}$ on dry weight basis). In general, fruit skin showed the highest antioxidant activity with fruit skin of P. domestica $\mathrm{L}$. subsp. domestica (extracted with $50 \%$ ethanol) showing a Trolox equivalent concentration of $1944.1 \mu \mathrm{M} / \mathrm{g}$, while fruit pulp of P. domestica subsp. syriaca (extracted with $99 \%$ ethanol) showed the lowest Trolox equivalent concentration of $585.5 \mu \mathrm{M} / \mathrm{g}$. On the basis of the higher polyphenol content, to which the inhibitory activity of the enzymes involved in MS is generally ascribed [29], the good antioxidant activity, the higher yield (49\%), and the lower percentage of ethanol used as extraction solvent (50\%), the P. domestica subsp. syriaca fruit pulp extract obtained with $50 \%$ hydroethanolic solution was selected for the subsequent chemical characterization.

Table 2. Total phenolic content and Trolox equivalent concentration of the extracts obtained from the two varieties of $P$. domestica.

\begin{tabular}{|c|c|c|c|}
\hline Prunus Variety & $\begin{array}{l}\text { Fruit Part Extracted } \\
\text { (Ethanol \%) }\end{array}$ & $\begin{array}{c}\text { TPC } \\
\text { (GAE/g } \\
\text { on Dry Weight Basis) }\end{array}$ & $\begin{array}{c}\text { Trolox Equivalent } \\
\text { Concentration }(\mu \mathrm{M} / \mathrm{g} \\
\text { on Dry Weight Basis) }\end{array}$ \\
\hline \multirow{6}{*}{$\begin{array}{l}\text { P. domestica subsp. } \\
\text { domestica }\end{array}$} & skin $(99 \%)$ & $9.1 \pm 1.0$ & $1282.4 \pm 84.1^{\mathrm{a}}$ \\
\hline & skin $(70 \%)$ & $12.8 \pm 0.9^{\mathrm{a}}$ & $1826.2 \pm 216.4$ \\
\hline & skin $(50 \%)$ & $11.0 \pm 0.6^{b}$ & $1944.1 \pm 138.1^{b}$ \\
\hline & pulp (99\%) & $7.2 \pm 1.0$ & $630.5 \pm 44.1^{\mathrm{a}}$ \\
\hline & pulp (70\%) & $11.3 \pm 0.2^{\mathrm{a}}$ & $1611.9 \pm 289.5$ \\
\hline & pulp (50\%) & $9.7 \pm 0.2^{b}$ & $1290.7 \pm 155.5^{b}$ \\
\hline \multirow{6}{*}{$\begin{array}{l}\text { P. domestica subsp. } \\
\text { syriaca }\end{array}$} & skin $(99 \%)$ & $7.0 \pm 0.2$ & $708.0 \pm 25.1$ \\
\hline & skin $(70 \%)$ & $11.2 \pm 1.4$ & $1597.4 \pm 88.2^{c}$ \\
\hline & skin $(50 \%)$ & $7.9 \pm 0.8^{c}$ & $1602.1 \pm 368.1$ \\
\hline & pulp $(99 \%)$ & $6.5 \pm 0.4$ & $578.5 \pm 53.5$ \\
\hline & pulp $(70 \%)$ & $10.0 \pm 0.9$ & $727.7 \pm 43.9^{c}$ \\
\hline & pulp (50\%) & $12.9 \pm 1.7^{\mathrm{c}}$ & $1119.4 \pm 93.1$ \\
\hline
\end{tabular}

Data are expressed as mean $\pm \mathrm{SD}(n=3)$. The assigned values of different letters in a column show significant difference among the mean values $(p<0.05)$; TPC, Total phenolic content.

Based on the assessment of total polyphenol content and antioxidant activity, on the higher yield (49\%), and the lower percentage of ethanol used as extraction solvent (50\%), the fruit pulp extract of $P$. domestica subsp. syriaca obtained with $50 \%$ hydroethanolic solution was selected, and in view of the high content of glucose and sucrose determined via NMR, it was subjected to the chemical precipitation of sugars by treatment with absolute ethanol, followed by ultra-freezing temperature. The organic solvent was removed under reduced pressure by a rotary evaporator, and the dry extract obtained from the fruit pulp extract of $P$. domestica subsp. syriaca without sugars was kept at $-20{ }^{\circ} \mathrm{C}$ for subsequent biological assays.

\subsection{UHPLC-HRMS Profile}

The list of the metabolites occurring in the hydroethanolic (50\%) extract obtained from P. domestica subsp. syriaca fruit pulp, with tentative identification based on accurate mass and fragmentation pattern compared against reference MS/MS spectra reported in silico and in previous literature, is reported in Table 3. In particular, 23 compounds belonging to different classes (organic and hydroxycinnamic acids and flavonoids, both aglycone and glycosylated) were identified in the extract (Figure 2). Hydroxycinnamic and quinic 
acid derivatives were the most abundant compounds, retaining the $46.7 \%$ of total peak area, followed by procyanidins, in particular dimer $(17 \%)$, monomers $(13.10 \%)$ and trimers (6.9\%). Lastly, flavonol glycosides represented the remaining $7.9 \%$. (Table 4 )

Table 3. Identified compounds in $P$. domestica subsp. syriaca fruit pulp extract according to the retention time (RT), compound, $m / z$ and MS/MS, molecular formula, and mass accuracy, reported as part per million (ppm) error.

\begin{tabular}{|c|c|c|c|c|c|c|}
\hline Peak & $\mathbf{r}_{\mathrm{t}}$ & Compound & {$[\mathrm{M}-\mathrm{H}]^{-}$} & MS/MS & $\begin{array}{l}\text { Molecular } \\
\text { Formula }\end{array}$ & $\begin{array}{l}\text { Error } \\
(\mathrm{ppm})\end{array}$ \\
\hline 1 & 0.60 & Citric acid & 191.0227 & $111.0103 ; 173.0103$ & $\mathrm{C}_{6} \mathrm{H}_{8} \mathrm{O}_{7}$ & 1.57 \\
\hline 2 & 3.12 & Chlorogenic acid & 353.0874 & $173.0489 ; 191.0576$ & $\mathrm{C}_{16} \mathrm{H}_{18} \mathrm{O}_{9}$ & -1.13 \\
\hline 3 & 4.68 & Coumaroylquinic acid Isomer & 337.0945 & $163.0417 ; 119.0558$ & $\mathrm{C}_{16} \mathrm{H}_{18} \mathrm{O}_{8}$ & 4.75 \\
\hline 4 & 5.45 & Catechin & 289.0729 & 245.0816 & $\mathrm{C}_{15} \mathrm{H}_{14} \mathrm{O}_{6}$ & 3.81 \\
\hline 5 & 6.08 & (+) Epicatechin dimer B type & 577.1328 & $407.0787 ; 289.0728$ & $\mathrm{C}_{30} \mathrm{H}_{26} \mathrm{O}_{12}$ & -4.16 \\
\hline 6 & 6.50 & Feruloylquinic acid & 367.1053 & $193.0531 ; 134.0390$ & $\mathrm{C}_{17} \mathrm{H}_{20} \mathrm{O}_{9}$ & 4.90 \\
\hline 7 & 6.70 & Coumaroylquinic acid isomer & 337.0928 & $163.0447 ; 191.0594$ & $\mathrm{C}_{16} \mathrm{H}_{18} \mathrm{O}_{8}$ & 1.19 \\
\hline 8 & 7.20 & Coumaroylquinic acid isomer & 337.0952 & $173.0458 ; 163.0418$ & $\mathrm{C}_{16} \mathrm{H}_{18} \mathrm{O}_{8}$ & 2.30 \\
\hline 9 & 8.12 & $(+)$ Epicatechin & 289.0735 & 245.0816 & $\mathrm{C}_{15} \mathrm{H}_{14} \mathrm{O}_{6}$ & 5.88 \\
\hline 10 & 8.48 & $(+)$ Epicatechin trimer B type & 865.1979 & $407.0790 ; 287.0569 ; 577.1344$ & $\mathrm{C}_{45} \mathrm{H}_{38} \mathrm{O}_{18}$ & 3.40 \\
\hline 11 & 8.86 & (+) Epicatechin dimer B type isomer & 577.1344 & $407.0790 ; 289.0732$ & $\mathrm{C}_{30} \mathrm{H}_{26} \mathrm{O}_{12}$ & -1.39 \\
\hline 12 & 9.70 & Quinic acid derivative & 393.1777 & $149.0465 ; 191.0561$ & $\mathrm{C}_{17} \mathrm{H}_{30} \mathrm{O}_{10}$ & 2.80 \\
\hline 13 & 10.50 & Feruloyl-coumaroylquinic acid derivative & 559.1665 & $337.0947 ; 193.0514$ & $\mathrm{C}_{24} \mathrm{H}_{32} \mathrm{O}_{15}$ & -0.54 \\
\hline 14 & 11.29 & Feruloyl-coumaroylquinic acid derivative & 559.1670 & $337.0949 ; 193.0510$ & $\mathrm{C}_{24} \mathrm{H}_{32} \mathrm{O}_{15}$ & -0.50 \\
\hline 15 & 12.19 & Feruloyl-coumaroylquinic acid derivative & 559.1677 & $337.0946 ; 193.0514$ & $\mathrm{C}_{24} \mathrm{H}_{32} \mathrm{O}_{15}$ & 1.61 \\
\hline 16 & 12.32 & $(+)$ Epicatechin dimer B type isomer & 577.1358 & $407.0831 ; 289.0742$ & $\mathrm{C}_{30} \mathrm{H}_{26} \mathrm{O}_{12}$ & 1.04 \\
\hline 17 & 12.74 & (+) Epicatechin B type trimer isomer & 865.2015 & $\begin{array}{c}407.0778 ; 287.0569 ; 577.1344 \\
543.0905\end{array}$ & $\mathrm{C}_{45} \mathrm{H}_{38} \mathrm{O}_{18}$ & 3.47 \\
\hline 18 & 13.20 & Quercetin-rutinoside & 609.1477 & $301.0351 ; 271.0254 ; 255.0320$ & $\mathrm{C}_{27} \mathrm{H}_{30} \mathrm{O}_{16}$ & 3.47 \\
\hline 19 & 13.48 & $(+)$ Epicatechin A type trimer & 863.1823 & $575.1180 ; 423.0711 ; 285.0393$ & $\mathrm{C}_{45} \mathrm{H}_{36} \mathrm{O}_{18}$ & -0.20 \\
\hline 20 & 14.04 & $(+)$ Epicatechin A type trimer isomer & 863.1828 & $575.1180 ; 423.0711 ; 285.0393$ & $\mathrm{C}_{45} \mathrm{H}_{36} \mathrm{O}_{18}$ & -0.12 \\
\hline 21 & 14.82 & $(+)$ Epicatechin A type dimer & 575.1197 & $423.0746 ; 285.0395$ & $\mathrm{C}_{30} \mathrm{H}_{24} \mathrm{O}_{12}$ & 1.22 \\
\hline 22 & 15.75 & Quercetin-rhamnoside & 447.0924 & $301.0371 ; 255$. & $\mathrm{C}_{21} \mathrm{H}_{20} \mathrm{O}_{11}$ & -0.9 \\
\hline 23 & 16.52 & $(+)$ Epicatechin A type dimer isomer & 575.1187 & $423.0716 ; 285.0398$ & $\mathrm{C}_{30} \mathrm{H}_{24} \mathrm{O}_{12}$ & -1.39 \\
\hline
\end{tabular}

Table 4. Retention time ( $\mathrm{min}$ ) and peak area, expressed as percentage of total area of the identified compounds in $P$. domestica subsp. syriaca fruit pulp extract.

\begin{tabular}{llll}
\hline Peak & Compound & Retention Time & $\begin{array}{l}\text { Area } \\
\%\end{array}$ \\
\hline 1 & Citric acid & 0.6 & 7.92 \\
2 & Chlorogenic acid & 3.12 & 15.43 \\
3 & Coumaroylquinic acid Isomer & 4.68 & 0.74 \\
4 & Catechin & 5.45 & 8.61 \\
5 & $(+)$ Epicatechin dimer B type & 6.08 & 5.74 \\
6 & Feruloylquinic acid & 6.5 & 0.21 \\
7 & Coumaroylquinic acid isomer & 6.7 & 0.39 \\
8 & Coumaroylquinic acid isomer & 7.2 & 2.42 \\
9 & (+) Epicatechin & 8.12 & 4.54 \\
\hline
\end{tabular}


Table 4. Cont.

\begin{tabular}{llll}
\hline Peak & Compound & Retention Time & $\begin{array}{l}\text { Area } \\
\%\end{array}$ \\
\hline 10 & (+) Epicatechin trimer B type & 8.48 & 0.24 \\
11 & $(+)$ Epicatechin dimer B type isomer & 8.86 & 5.47 \\
12 & Quinic acid derivative & 9.7 & 1.98 \\
13 & Feruloyl-coumaroylquinic acid derivative & 10.5 & 3.01 \\
14 & Feruloyl-coumaroylquinic acid derivative & 11.29 & 19.55 \\
15 & Feruloyl-coumaroylquinic acid derivative & 12.19 & 1.49 \\
16 & Feruloyl-coumaroylquinic acid derivative & 12.32 & 1.47 \\
17 & (+) Epicatechin dimer B type isomer & 12.74 & 6.27 \\
18 & (+) Epicatechin B type trimer isomer & 13.2 & 0.79 \\
19 & Quercetin-rutinoside & 13.48 & 3.20 \\
20 & (+) Epicatechin A type trimer & 14.04 & 4.05 \\
21 & (+) Epicatechin A type trimer isomer & 14.82 & 1.81 \\
22 & (+) Epicatechin A type dimer & 15.75 & 0.16 \\
23 & Quercetin-rhamnoside & 16.52 & 4.50 \\
\hline
\end{tabular}

\section{A}

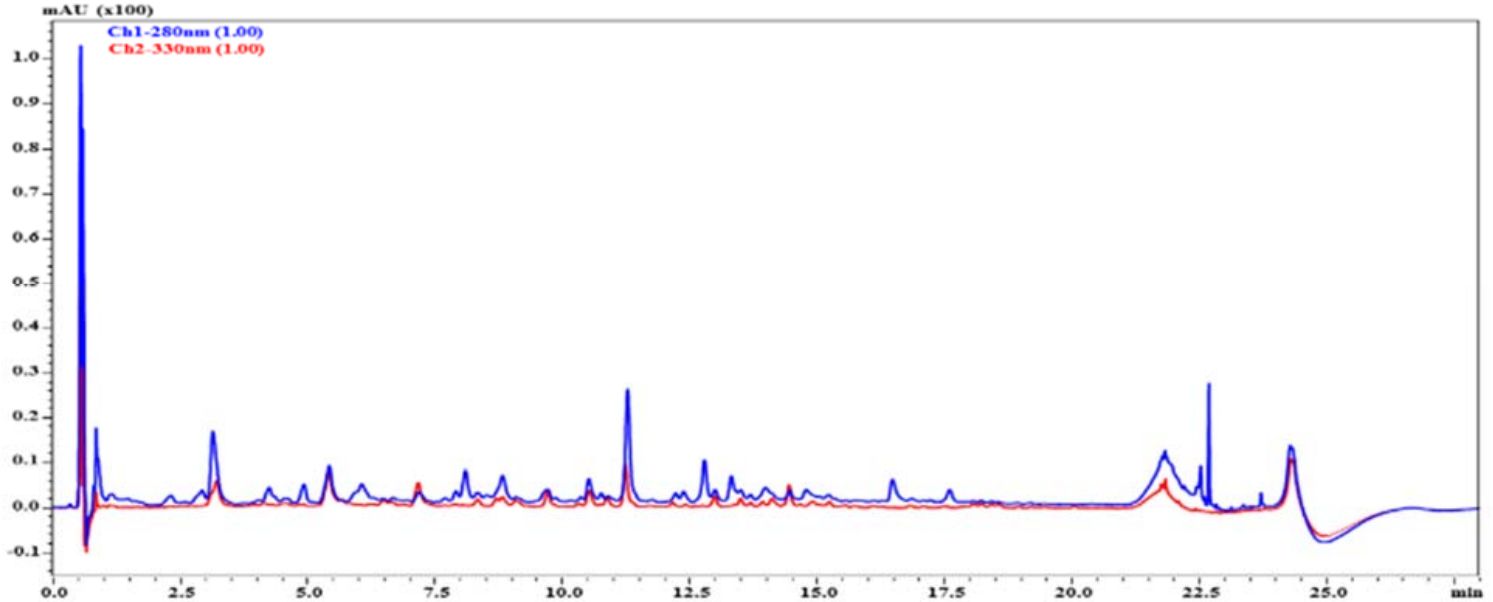

B

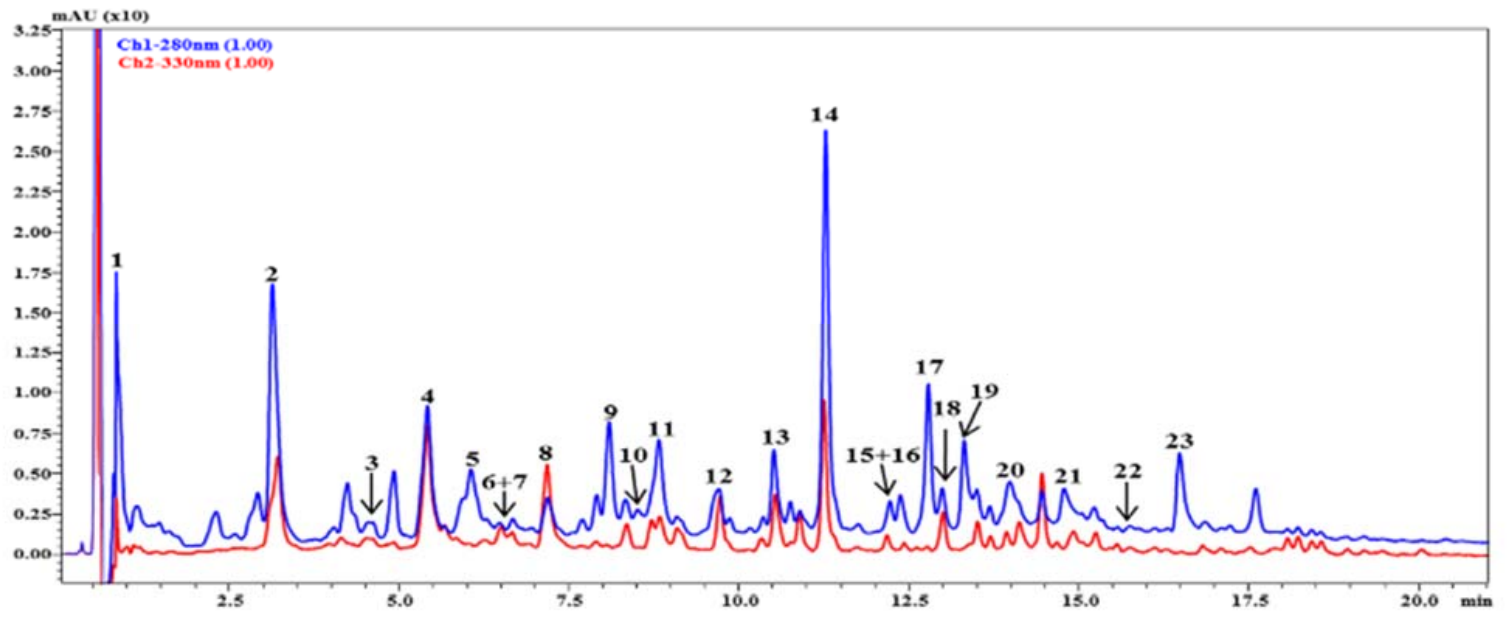

Figure 2. RP-UHPLC chromatograms of $P$. domestica subsp. syriaca fruit pulp extract with UV detection registered at $\lambda 280 \mathrm{~nm}$ and $330 \mathrm{~nm}(\mathbf{A})$, and chromatogram expansion with corresponding peak HRMS assignment (B). 


\subsection{NMR Analysis and Quantification of Sugar and Organic Acid Contents}

The ${ }^{1} \mathrm{H}$ spectrum of the $P$. domestica subsp. syriaca fruit pulp extract dissolved in phosphate buffer/D2O shows the presence of glucose, sucrose, xylose and citric, malic and quinic acids. The ${ }^{1} \mathrm{H}$ spectral assignment was obtained by literature data regarding other fruits $[36,37]$ and 2D NMR experiments [38]. The integrals of selected signals due to sugars, namely xylose, glucose, and sucrose at $5.20 \mathrm{ppm}, 5.25 \mathrm{ppm}$, and $5.42 \mathrm{ppm}$, respectively, and to organic acids, namely citric, malic and quinic acids at $1.88 \mathrm{ppm}, 2.54 \mathrm{ppm}$, and $4.30 \mathrm{ppm}$, respectively, were used for compound quantification (Table 5). The ${ }^{1} \mathrm{H}$ NMR spectrum with the selected signals used for the quantification of metabolites (Figure 3) and the compound assignments table (Table S1) was also reported. In the case of some compounds, only a partial assignment was obtained due to low concentration of the compound. However, the partial assignment included diagnostic signals that allowed the identification of the reported compounds. Glucose and malic acid turned out to be the sugar and the organic acid, respectively, present in major amounts.

Table 5. Compounds identified in the ${ }^{1} \mathrm{H}$ NMR spectrum of $P$. domestica subsp. syriaca fruit pulp extract dissolved in phosphate buffer/D2O and the corresponding chemical shift signals (ppm) used in the integration process. The compound amounts in $\mu \mathrm{g} / \mathrm{mg}$ of dry weight are also reported.

\begin{tabular}{ccc}
\hline Compound & $\begin{array}{c}\text { Chemical Shift (ppm) of Selected Resonances Used } \\
\text { for Quantification }\end{array}$ & $\mu \mathrm{g} / \mathbf{m g}$ Dry Weight \\
\hline Quinic acid & $1.88(\mathrm{CH}-1)$ & 7.50 \\
Citric acid & $2.54(\alpha, \gamma-\mathrm{CH})$ & 0.84 \\
Malic acid & $4.30(\alpha-\mathrm{CH})$ & 38.49 \\
Xylose & $5.20(\mathrm{CH}-1)$ & 0.56 \\
Glucose & $5.25(\mathrm{CH}-1)$ & 106.59 \\
Sucrose & $5.42(\mathrm{CH}-1)$ & 31.59 \\
\hline
\end{tabular}

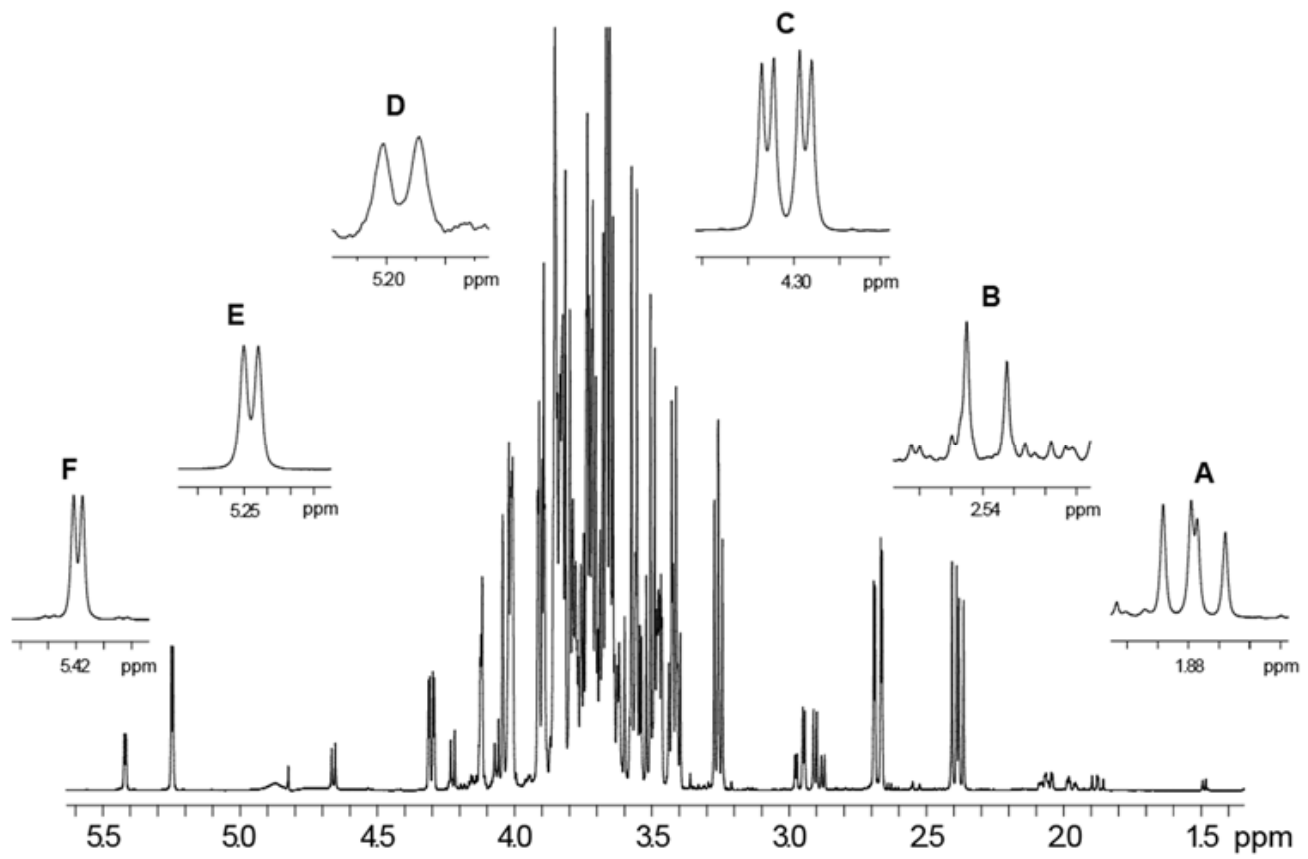

Figure 3. ${ }^{1} \mathrm{H}$ NMR spectrum of $P$. domestica subsp. syriaca fruit pulp extract. Quantified selected NMR signals are reported in expanded regions. (A) $\mathrm{CH} 2-1$ protons of quinic acid (1.88 ppm), (B) $\alpha, \gamma-\mathrm{CH}$ protons of citric acid (2.54 ppm), (C) $\alpha-\mathrm{CH}$ proton of malic acid (4.30 ppm), (D) CH-1 proton of in $\alpha$-xylose (5.20 ppm), (E) CH-1 proton of $\alpha$-glucose (5.25 ppm), (F) $\mathrm{CH}-1$ proton of sucrose (5.42 $\mathrm{ppm}$ ). 


\subsection{Preparation of P. domestica Fruit Extract without Sugar}

In view of the high sugar content (about $14 \%$ of the whole extract) of $P$. domestica subsp. syriaca fruit pulp crude extract, it was subjected to chemical precipitation of sugar contents by treatment with absolute ethanol, supported by ultra-freezing temperature. The percent extraction yield following sugar precipitation was $41.8 \%$.

\subsection{Effect of P. domestica Subsp. Syriaca Fruit Pulp Extract on Enzyme Activities}

P. domestica subsp. syriaca fruit pulp extract with reduced content of sugars was used for enzyme inhibition activities, with the aim of reducing the substances that may interfere with the enzyme inhibition activities of the vegetable extract. The inhibition of the enzyme activities performed by the extract at increasing concentration and the IC50 values for each enzyme, calculated with the nonlinear regression analysis, have been illustrated in Figure 4.

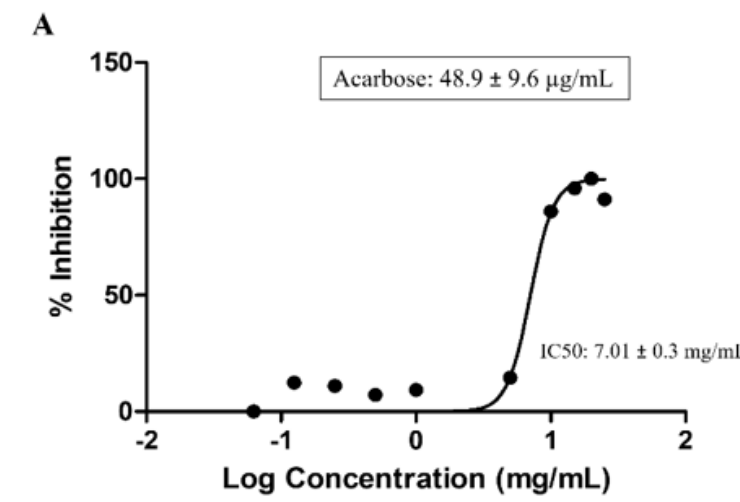

C

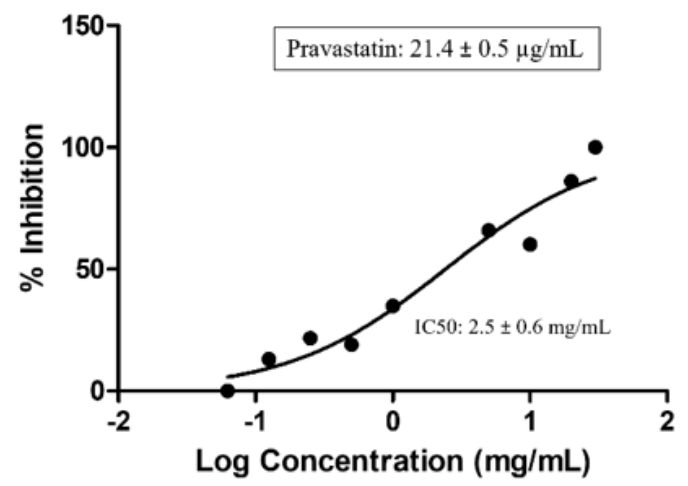

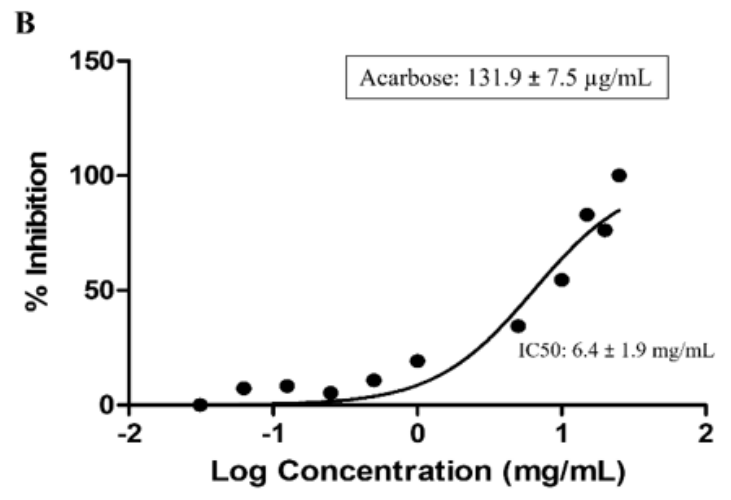

D

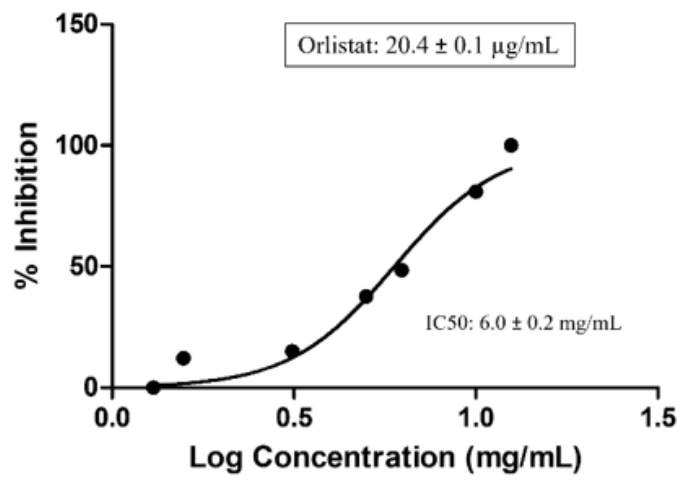

Figure 4. Enzyme inhibition activities and calculated IC50 values of $P$. domestica subsp. syriaca fruit pulp extract. $\alpha$-amylases inhibition (A), $\alpha$-glucosidase inhibition (B), HMG CoA reductase inhibition (C), Pancreatic lipase inhibition (D). Data expressed as mean \pm SD. The IC50 values of the fruit extract against each enzyme were calculated using nonlinear regression analysis.

P. domestica subsp. syriaca fruit pulp extract inhibited $\alpha$-amylase and $\alpha$-glucosidase enzymes in a concentration-dependent manner, with an IC50 value of $7.01 \mathrm{mg} / \mathrm{mL}$ compared to acarbose, used as positive control (IC50: $48.9 \mu \mathrm{g} / \mathrm{mL}$ ) (Figure 4A), and IC50 value of $6.4 \mathrm{mg} / \mathrm{mL}$ compared to acarbose (IC50: $131.9 \mu \mathrm{g} / \mathrm{mL}$ ) (Figure 4B), respectively. As far as HMG-CoA reductase is concerned, $P$. domestica subsp. syriaca fruit extract inhibited HMG-CoA reductase enzyme in a concentration-dependent manner with an IC50 value of $2.5 \mathrm{mg} / \mathrm{mL}$, while the reference inhibitor pravastatin inhibited HMG-CoA reductase with an IC50 value of $21.4 \mu \mathrm{g} / \mathrm{mL}$ (Figure 4C). Finally, regarding pancreatic lipase, the results suggest that $P$. domestica subsp. syriaca fruit pulp extract inhibited this enzyme in a 
concentration-dependent manner with an IC50 value of $6.0 \mathrm{mg} / \mathrm{mL}$ compared to reference inhibitor orlistat (IC50 value: $20.4 \mu \mathrm{g} / \mathrm{mL}$ ) (Figure 4D). Overall, the mean IC50 values of the fruit extract were found to be significantly different from the values obtained from the positive controls $(p<0.05)$.

\subsection{In Vitro Anti-Inflammatory Effects of P. domestica Subsp. Syriaca Fruit Pulp Extract}

In order to assess the anti-inflammatory proprieties of $P$. domestica subsp. syriaca fruit pulp extract, murine macrophage cell line J774 stimulated with LPS (10 $\mathrm{g} / \mathrm{mL}, 24 \mathrm{~h})$, a well-known proinflammatory stimulus, was used. The anti-inflammatory activities were assessed by measuring the levels of proinflammatory mediators such as nitrites, $\mathrm{PGE}_{2}$ and IL-1 $\beta$. Preincubation of J774 macrophages with $P$. domestica subsp. syriaca fruit pulp extract ( $2 \mathrm{~h}$ before LPS treatment) inhibited significantly and in a concentration-dependent manner $(0.01,0.1,0.5,0.75$ and $1 \mathrm{mg} / \mathrm{mL})$ the production of nitrite (IC50 $0.46 \mathrm{mg} / \mathrm{mL}$, Figure 5A), PGE 2 (IC50 $0.56 \mathrm{mg} / \mathrm{mL}$, Figure 5B) and IL-1 $\beta$ (IC50 $0.18 \mathrm{mg} / \mathrm{mL}$, Figure 5C) induced by LPS, starting from the concentration of $0.1 \mathrm{mg} / \mathrm{mL}$. No effects of P. domestica subsp. syriaca fruit pulp extract on proinflammatory mediator production were observed in unstimulated cells (without LPS) (Figure 5D-F). To rule out any alteration of cell viability, an MTT assay was performed and did not show any statistical reduction in cell viability after treatment with extract (Figure 5G).
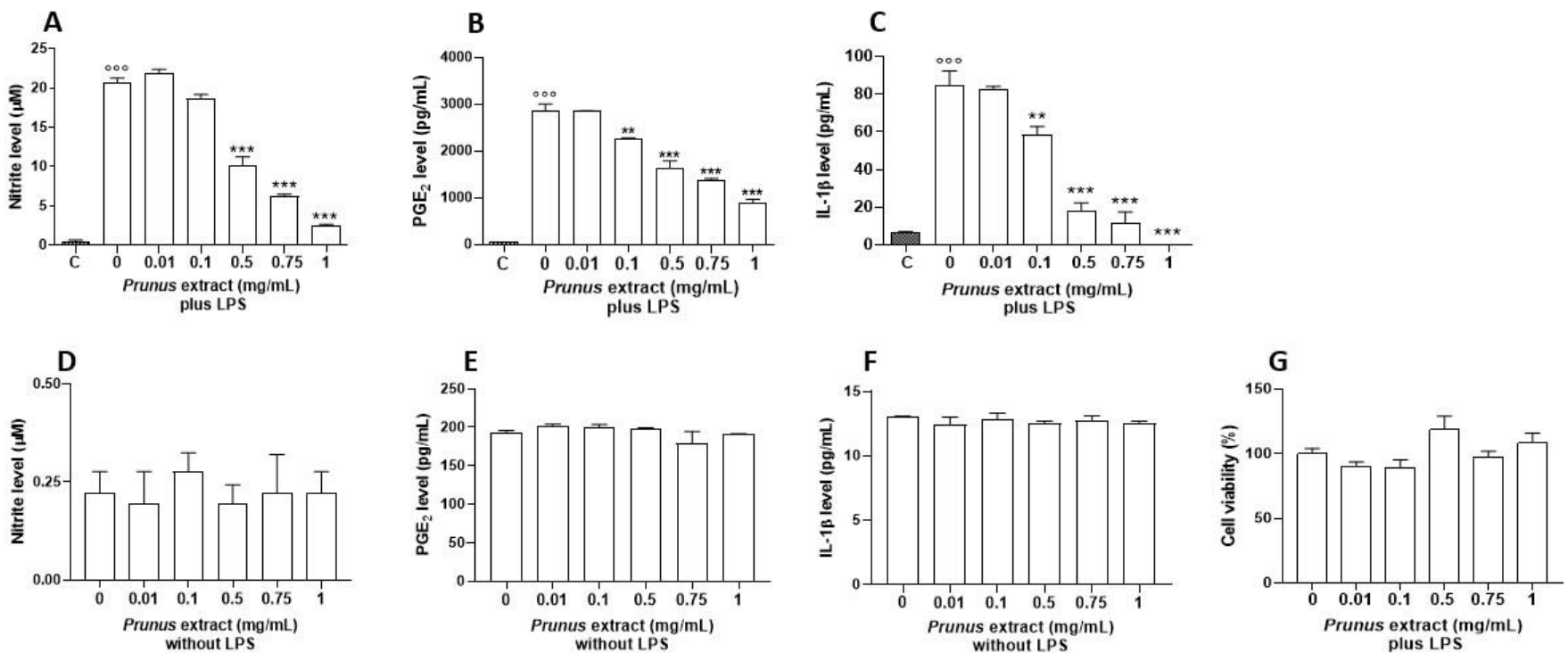

Figure 5. Effect of the P. domestica subsp. syriaca fruit pulp extract on LPS-induced nitrite, IL- $1 \beta$ and $\mathrm{PGE}_{2}$ production. $\mathrm{J774}$ cells were pretreated for $2 \mathrm{~h}$ with increasing concentrations of the extract ('0.01'. '0.1'. '0.5'. '0.75'. and ' 1 ' $\mathrm{mg} / \mathrm{mL}$ ) and then stimulated with LPS ('10' $\mu \mathrm{g} / \mathrm{mL}$ ) for $24 \mathrm{~h}$ (plus LPS). Effects of extract were also evaluated in absence of LPS (without LPS). Unstimulated J774 cells acted as a negative control $(\mathbf{C})$. Nitrites $(\mathbf{A}, \mathbf{D})$, stable end products of NO, were measured in the supernatants by the Griess reaction, whereas IL-1 $\beta(\mathbf{B}, \mathbf{E})$ and $\mathrm{PGE}_{2}(\mathbf{C}, \mathbf{F})$ were measured by ELISA. Cell viability was evaluated by the mitochondrial-dependent reduction of MTT to formazan (G). ○० $p<0.001$ vs. unstimulated cells (C), $p<0.001$ vs. unstimulated cells $(\mathbf{C}),{ }^{* * *} p<0.001$ and ${ }^{* *} p<0.01$ vs. LPS alone.

\section{Discussion}

The World Health Organization (WHO) reports that approximately 650 million people live today with obesity, 422 million with T2DM and 1.13 billion people with hypertension [39-41]. Thus, metabolic disorders remain a prevalent and urgent concern in the healthcare field, which today are remedied through pharmacological approaches prescribed to target some specific pathogenetic mechanisms. This, in turn, is often accompanied by adverse effects and poor compliance by patients. [42]. Therefore, the study of new food 
supplement ingredients for the reduction of risk factors of MS is essential and finding new agents able to modulate the enzyme activities associated with carbohydrate/lipid digestion and cardiometabolic diseases is one of the essential targets in the prevention and treatment of cardiometabolic disorders. As evident by preclinical and clinical trials, Prunus species can improve energy homeostasis involving glucose and lipid metabolism, decrease inflammatory mediators, reduce lipid deposition, and modulate gut microbiota, and thus can reverse metabolic dysregulation states [43]. In this study, we explored the ability of a hydroethanolic extract of $P$. domestica subsp. syriaca (Mirabelle plum) fruit pulp to inhibit the activity of various enzymes associated with cardiometabolic disorders. Initially, fruit skin and pulp of two different $P$. domestica varieties (Common plum and Mirabelle plum), extracted with different concentrations of ethanolic solution, were evaluated for TPC, and the Mirabelle plum extract showing the highest TPC was selected for enzyme inhibition assays and evaluation of in vitro anti-inflammatory activity. Chemical profiling of $P$. domestica subsp. syriaca fruit pulp extract was evaluated using a multimethodological approach based on the application of new technologies, consisting of untargeted NMR spectroscopy and untargeted UHPLC-HRMS, which favors a holistic approach as opposed to the traditional reductionist methods, allowing us to overcome the concept of identifying one compound responsible for the obtained biological effect, and to ascribe the bioactivity to the whole phytocomplex [44]. The results suggested the presence of hydroxycinnamic acids (p-coumaroylquinic acid isomers and feruloylquinic acid derivatives), which resulted to be the most represented polyphenols followed by flavanols (catechin, epicatechin, procyanidins), flavonols (rutinoside and rhamnoside derivatives of quercetin), organic acids (quinic acid, citric acid, and malic acid), and carbohydrates (xylose, glucose, and sucrose). The carbohydrate quantitative analysis showed that glucose $(106.6 \mathrm{mg} / \mathrm{g}$ dry weight of extract) is the main saccharide found in the fruit extract, in agreement with USDA Food Composition Databases, followed by sucrose $(31.6 \mathrm{mg} / \mathrm{g}$ dry weight of extract) and xylose $(0.6 \mathrm{mg} / \mathrm{g}$ dry weight of extract). Sugars of the fruit extract were at least in part chemically precipitated with ethanol before proceeding with the enzyme inhibition and the anti-inflammatory assays to remove the constituents that may interfere with the biological activities of the vegetable extract. The inhibition of $\alpha$-amylase and $\alpha$-glucosidase enzymes are important to reduce the digestion of complex carbohydrates and in turn the absorption of glucose, with the aim to normalize the blood glucose level both in subjects with mild hyperglycemia and in diabetic patients, to support glucose-lowering medication [19]. Acarbose is a pharmacologic drug currently employed in the treatment of subjects with diabetes due to its potential to inhibit $\alpha$-amylase and $\alpha$-glucosidase enzymes, thus reducing carbohydrate digestion, slowing down the absorption of carbohydrates, and decreasing postprandial insulin secretion, in addition to stimulating glucagon-like peptide (GLP-1) release [45]. The extract of $P$. domestica subsp. syriaca fruit pulp showed inhibitory activity against $\alpha$-amylase and $\alpha$-glucosidase enzymes with IC50 values of $7.01 \mathrm{mg} / \mathrm{mL}$ and $6.4 \mathrm{mg} / \mathrm{mL}$, respectively. While evaluating antidiabetic activity of novel smoothies from selected Prunus fruits, Nowicka et al. demonstrated that anthocyanin and flavonol content have the highest impact on $\alpha$-glucosidase enzyme, whereas flavanols may have the potential to inhibit $\alpha$-amylase [46]. Some studies also reported that inhibition of $\alpha$-glucosidase may be associated with the content of hydroxycinnamic acid derivatives such as ferulic acid or $p$-coumaric acids [47]. The researchers indicated that flavonols can interact with hydroxycinnamic acids or anthocyanins, which may increase the inhibition of $\alpha$-glucosidase [48]. It has also been suggested that procyanidins-rich fruits are effective $\alpha$-amylase inhibitors, possibly by the formation of enzyme-tannin complexes resulting in the prevention of the enzyme from interacting with starch [48]. The literature shows an inhibition of $\alpha$-amylase and $\alpha$-glucosidase enzymes with numerous botanical extracts, including Elateriospermum tapos Blume [49], Xylopia parviflora Spruce, Monodora myristica (Gaertn.) Dunal, Tetrapleura tetraptera (Schum. \& Thonn.) Taub., Dichrostachys glomerata (Forssk.) Chiov., Aframomum melegueta K.Schum., Aframomum citratum (C.Pereira) K.Schum [34] and Adansonia digitata L. [33]. Different Prunus fruits (including Common European plum, 'vlaškača', damson 
plum, white damson, purple-leaf cherry plum, white cherry plum, red cherry plum, sweet cherry, sweet cherry-wild type, sour cherry, steppe cherry, mahaleb cheery, blackthorn, and peach) extracted with $50 \%$ ethanol exhibited inhibition of $\alpha$-amylase (IC50 value range: $1.11-136.23 \mathrm{mg} / \mathrm{mL}$ ) and $\alpha$-glucosidase (IC50 value range: $0.41-28.44 \mathrm{mg} / \mathrm{mL}$ ) [50]. Prunus species in general showed a greater affinity towards $\alpha$-glucosidase enzyme compared to $\alpha$-amylase [50]. Altogether, these data suggest that inhibition of the enzymes involved in the digestion of carbohydrates by vegetable extracts may have promising potential in the management of glucose metabolism disorders. Statins are effective lipid-lowering agents, widely used as a first-line therapy in the atherosclerotic CVDs, which are known to competitively inhibit HMG-CoA reductase enzyme (rate-limiting enzyme of cholesterol synthesis) [51]. Considering the same approach of decreasing cholesterol synthesis, P. domestica subsp. syriaca fruit pulp extract was tested against the HMG-CoA reductase activity, showing an IC50 value of $2.5 \mathrm{mg} / \mathrm{mL}$. The mean IC50 value calculated for the fruit extract was significantly higher from the reference statin (pravastatin). Susilowati et al. (2020) performed in silico analysis while evaluating antihyperlipidemic effects of apple peel extract, which showed the highest HMG CoA reductase inhibition by catechin, epicatechin, quercetin (aglycosidal form) and chlorogenic acid [52]. Several other vegetable extracts have already shown HMG-CoA reductase inhibitory activities, including, but not limited to Basella alba L. [53], Syzygium polyanthum (Wight) Walp. [54], Ficus palmata Forssk. [55], and Amaranthus viridis L. [56]. Inhibition of pancreatic lipase is a clinically validated approach in the treatment of obesity, as it reduces the hydrolysis of fats and decreases their absorption [57]. The Food and Drug Administration (FDA) approved orlistat in 1999 for the pharmacological management of obesity in conjunction with a reduced caloric diet, while in 2007 it was approved as an over-the-counter (OTC) agent for weight loss in overweight adults (18 years or older) [58]. Later, the FDA revised the label for orlistat by adding a new warning about severe liver injury, which has been reported rarely with this drug [59]. Following concerns about the possible cause of severe hepatic toxicities with orlistat, the European Medicines Agency completed a review for this medicine, where the Agency's Committee for Medicinal Products for Human Use (CHMP) concluded that the benefits of orlistat continue to outweighs the risks, but also recommended that marketing authorizations should ensure that the safety information on rarely occurring liver injuries be provided on the product information of all orlistat-containing medicines [60]. As reported in the present study, P. domestica subsp. syriaca fruit pulp extract inhibited the pancreatic lipase enzyme with an IC50 value of $6.0 \mathrm{mg} / \mathrm{mL}$, although this value was significantly higher than that determined for orlistat. Hydroxycinnamic acids and proanthocyanidins have proven efficacy against lipase activity [61,62]. The presence of hydroxyl groups in the molecule (more potent), methoxy groups (less potent) and position of hydroxyl groups in the phenolic ring could influence the activity of polyphenols in inhibiting lipase enzyme [61]. Moreover, flavan-3-ol esters showed a stronger lipase inhibition compared to non-esterified flavanols such as catechin and epicatechin [61]. Plant species of different families (Vitis vinifera L., Rhus coriaria L., Origanum dayi Post, Quercus infectoria G.Olivier, Eucalyptus galbie, Rosa damascene, and Levisticum officinale W.D.J.Koch) showed considerable inhibition of pancreatic lipase enzyme $[63,64]$. Nowicka et al. observed an inhibition of pancreatic lipase enzyme with Prunus persica L. Batsch fruits (different cultivars), with an IC50 value ranging from 0.07 to $2.06 \mathrm{mg} / \mathrm{mL}$ [65]. On the whole, although the values of IC50 are much higher than those found for drugs, it must be considered that the extract, being derived from a food commonly consumed in diet and having been deprived of sugars, should not show adverse effects unlike medicines, and therefore it can be taken in larger quantities and for very long periods. In vivo studies are needed to confirm inhibitory activity against the enzymes considered. Lifestyle modifications (including diet and exercise) and pharmacological agents (such as peroxisome proliferator-activated receptor (PPAR)- $\alpha$ agonists, angiotensin-converting enzyme (ACE) inhibitors and angiotensin receptor blockers (ARBs)) all target inflammation in various ways, and thus can reduce MS-associated complications. Ongoing research studies are uncovering inflammatory pathways (related 
to obesity, T2DM, and MS), which may be potential targets for novel preventive and treatment strategies with the aim of improving overall patient quality of life and reducing mortality, preferentially by preventing the adverse sequelae from MS [66]. P. domestica subsp. syriaca fruit pulp extract showed promising results against nitrite, IL- $1 \beta$, and PGE 2 levels in LPS-stimulated macrophages in a concentration-dependent manner, with an IC50 of $0.46,0.18$ and $0.56 \mathrm{mg} / \mathrm{mL}$, respectively. These results are in agreement with those previously published $[67,68]$, although our extract was more active. In particular, dried plum polyphenols significantly suppressed the production of NO and COX-2 in LPS-stimulated RAW 264.7 macrophages at the concentration of 100 and $100 \mathrm{mg} / \mathrm{mL}$, respectively [68]. The higher anti-inflammatory effects of $P$. domestica subsp. syriaca fruit pulp extract could be due to the presence of polyphenolic compounds in different concentrations, mainly flavonoids (catechin and (+) epicatechin) and hydroxy cinnamic acids (chlorogenic acid and feruloyl-coumaroylquinic acid derivative). Each compound inhibited the production of proinflammatory mediators at different concentrations, and whether the anti-inflammatory effects of this prunus extract are due to additively or synergistically polyphenolic action is not known. For example, inhibitory effects of catechin [69] and chlorogenic acid [70] on various inflammatory mediators using LPS-stimulated RAW 264.7 macrophages were reported. In particular, chlorogenic acid completely inhibited NO production in LPSstimulated macrophage RAW 264.7 cells at the concentration of $40 \mathrm{ug} / \mathrm{mL}$ [70]. A medicinal plant Inonotus (I.) sanghuang (rich in rutin, chlorogenic acid, isorhamnetin, quercetin, and quercitrin) improved insulin resistance and MS by reducing inflammation via modulation of the crosstalk between macrophages and adipocytes [71]. Grape powder extract (rich in quercetin-3-glucoside, catechin, epicatechin, rutin, gallic acid and resveratrol) showed to decrease LPS-stimulated inflammation in macrophages by affecting the gene expression of IL-6, IL-8, IL-1 $\beta$ and TNF- $\alpha$, and in turn decreased insulin resistance [72]. Sambucus nigra L. fruit extract alleviated insulin resistance by suppressing the enhanced production of $\mathrm{NO}$, TNF- $\alpha$, IL-6, and PGE 2 , where the presence of cyanidin-based anthocyanins, flavan-3-ols, flavonols, and hydroxycinnamic acids were detected [73].

The main strength of this study is represented by the comprehensive characterization of the P. domestica extract by different and complementary technologies and the evaluation of some in vitro functional activities of this extract on mechanisms related to the pathophysiology of cardiometabolic diseases. A limitation of this study is that we did not evaluate additional specific aspects, such as modulation of triglyceride content or glucose uptake in appropriate cell models. The assessment of these and other related parameters will be the object of future research, in order to complete the functional characterization of $P$. domestica extracts and lay the scientific foundations for the placing on the market of new food supplements based on P. domestica extracts.

\section{Conclusions}

Nutraceuticals and functional foods are known to play an important role in the maintenance of human health and wellbeing through the prevention of chronic diseases. A substantial increase in the worldwide usage of vegetable extracts has been observed in recent decades, probably due to the increasing trend of consumer propensity towards preventive care through natural substances. Currently, more than $80 \%$ of world population is relying on the use of vegetable products for their primary health concerns [74]. The present investigation studied the potential nutraceutical benefits of $P$. domestica subsp. syriaca fruit pulp extract and found that it inhibited key enzymes involved in the metabolism of carbohydrates and lipids as well as in cholesterol synthesis, and attenuated LPS-stimulated release of proinflammatory mediators. The chemical characterization showed the presence of polyphenolic contents, which potentially justifies these biological properties. Taken together, these findings point towards a potential to modulate some molecular mechanisms involved in the pathophysiology of cardiometabolic diseases. Further studies using in vitro and in vivo models are required to better characterize these properties and their potential applications for human health. 
Supplementary Materials: The following are available online at https://www.mdpi.com/article/10 $.3390 /$ nu14020340/s1, Table S1: Sugars and organic acids identified in the $600.17 \mathrm{MHz}^{1} \mathrm{H}$ spectra of P. domestica fruit pulp extracts. Asterisks indicate signals selected for integration.

Author Contributions: Conceptualization, M.D.(Maria Daglia), P.M. and A.D.M.; methodology, H.U., E.S., C.S., D.D. and G.D.M.; software, H.U., A.R., M.D.(Marco Dacrema); validation, H.U., E.S., C.S. and A.R.; formal analysis, H.U., A.R., L.M. and P.C.; investigation, H.U., E.S., A.R. and P.C.; resources, H.U., A.R., M.D.(Marco Dacrema) and P.C.; data cura1tion, H.U. and C.S.; writing-original draft preparation, H.U., E.S., C.S., and A.R.; writing-review and editing, H.U., E.S., C.S., A.R., P.M. and M.D.(Maria Daglia); visualization, H.U. and M.D.(Maria Daglia); supervision, M.D.(Maria Daglia). All authors have read and agreed to the published version of the manuscript.

Funding: This research received no external funding.

Informed Consent Statement: Not applicable.

Conflicts of Interest: The authors declare no conflict of interest.

\section{References}

1. Belwal, T.; Bisht, A.; Devkota, H.P.; Ullah, H.; Khan, H.; Pandey, A.; Bhatt, I.D.; Echeverría, J. Phytopharmacology and Clinical Updates of Berberis Species against Diabetes and Other Metabolic Diseases. Front. Pharmacol. 2020, 11, 41. [CrossRef] [PubMed]

2. Costa, L.A.; Canani, L.H.; Lisbôa, H.R.K.; Tres, G.S.; Gross, J.L. Aggregation of Features of the Metabolic Syndrome Is Associated with Increased Prevalence of Chronic Complications in Type 2 Diabetes. Diabet Med. 2004, 21, 252-255. [CrossRef]

3. McCracken, E.; Monaghan, M.; Sreenivasan, S. Pathophysiology of the Metabolic Syndrome. Clin. Dermatol. 2018, 36, 14-20. [CrossRef] [PubMed]

4. $\quad$ Åberg, F.; Helenius-Hietala, J.; Puukka, P.; Färkkilä, M.; Jula, A. Interaction between Alcohol Consumption and Metabolic Syndrome in Predicting Severe Liver Disease in the General Population. Hepatology 2018, 67, 2141-2149. [CrossRef]

5. Mongraw-Chaffin, M.; Foster, M.C.; Anderson, C.A.M.; Burke, G.L.; Haq, N.; Kalyani, R.R.; Ouyang, P.; Sibley, C.T.; Tracy, R.; Woodward, M.; et al. Metabolically Healthy Obesity, Transition to Metabolic Syndrome, and Cardiovascular Risk. J. Am. Coll. Cardiol. 2018, 71, 1857-1865. [CrossRef]

6. Scarpellini, E.; Tack, J. Obesity and Metabolic Syndrome: An Inflammatory Condition. Dig. Dis. 2012, 30, 148-153. [CrossRef]

7. Magni, P.; Liuzzi, A.; Ruscica, M.; Dozio, E.; Ferrario, S.; Bussi, I.; Minocci, A.; Castagna, A.; Motta, M.; Savia, G. Free and Bound Plasma Leptin in Normal Weight and Obese Men and Women: Relationship with Body Composition, Resting Energy Expenditure, Insulin-sensitivity, Lipid Profile and Macronutrient Preference. Clin. Endocrinol. 2005, 62, 189-196. [CrossRef]

8. Popko, K.; Gorska, E.; Stelmaszczyk-Emmel, A.; Plywaczewski, R.; Stoklosa, A.; Gorecka, D.; Pyrzak, B.; Demkow, U. Proinflammatory Cytokines Il-6 and TNF- $\alpha$ and the Development of Inflammation in Obese Subjects. Eur. J. Med. Res. 2010, 15, 120-122. [CrossRef]

9. Tangvarasittichai, S.; Pongthaisong, S.; Tangvarasittichai, O. Tumor Necrosis Factor-A, Interleukin-6, C-Reactive Protein Levels and Insulin Resistance Associated with Type 2 Diabetes in Abdominal Obesity Women. Indian J. Clin. Biochem. 2016, 31, 68-74. [CrossRef] [PubMed]

10. Chakraborty, S.; Roy, S.; Rahaman, M. Epidemiological Predictors of Metabolic Syndrome in Urban West Bengal, India. J. Family Med. Prim. Care 2015, 4, 535. [CrossRef]

11. de Filippis, A.; Ullah, H.; Baldi, A.; Dacrema, M.; Esposito, C.; Garzarella, E.U.; Santarcangelo, C.; Tantipongpiradet, A.; Daglia, M. Gastrointestinal Disorders and Metabolic Syndrome: Dysbiosis as a Key Link and Common Bioactive Dietary Components Useful for Their Treatment. Int. J. Mol. Sci. 2020, 21, 4929. [CrossRef] [PubMed]

12. Prasad, H.; Ryan, D.A.; Celzo, M.F.; Stapleton, D. Metabolic Syndrome: Definition and Therapeutic Implications. Postgrad. Med. 2012, 124, 21-30. [CrossRef] [PubMed]

13. Rask Larsen, J.; Dima, L.; Correll, C.U.; Manu, P. The Pharmacological Management of Metabolic Syndrome. Expert Rev. Clin. Pharmacol. 2018, 11, 397-410. [CrossRef] [PubMed]

14. Matfin, G. Developing Therapies for the Metabolic Syndrome: Challenges, Opportunities, and the Unknown. Ther. Adv. Endocrinol. Metab. 2010, 1, 89-94. [CrossRef] [PubMed]

15. Russo, R.; Gallelli, L.; Cannataro, R.; Perri, M.; Calignano, A.; Citraro, R.; Russo, E.; Gareri, P.; Corsonello, A.; de Sarro, G. When Nutraceuticals Reinforce Drugs Side Effects: A Case Report. Curr. Drug Saf. 2016, 11, 264-266. [CrossRef]

16. Li, X.T.; Liao, W.; Yu, H.J.; Liu, M.W.; Yuan, S.; Tang, B.W.; Yang, X.H.; Song, Y.; Huang, Y.; le Cheng, S.; et al. Combined Effects of Fruit and Vegetables Intake and Physical Activity on the Risk of Metabolic Syndrome among Chinese Adults. PLoS ONE 2017, 12, e0188533. [CrossRef]

17. EFSA Panel on Food Additives and Nutrient Sources added to Food (ANS); Younes, M.; Aggett, P.; Aguilar, F.; Crebelli, R.; Dusemund, B.; Filipič, M.; Frutos, M.J.; Galtier, P.; Gott, D.; et al. Scientific Opinion on the Safety of Monacolins in Red Yeast Rice. EFSA J. 2018, 16, e05368.

18. Birari, R.B.; Bhutani, K.K. Pancreatic Lipase Inhibitors from Natural Sources: Unexplored Potential. Drug Discov. 2007, 12, 879-889. [CrossRef] [PubMed] 
19. Tundis, R.; Loizzo, M.R.; Menichini, F. Natural Products as $\alpha$-Amylase and $\alpha$ Glucosidase Inhibitors and Their Hypoglycaemic Potential in the Treatment of Diabetes: An Update. Mini Rev. Med. Chem. 2010, 10, 315-331. [CrossRef]

20. Lin, S.-H.; Huang, K.-J.; Weng, C.-F.; Shiuan, D. Exploration of Natural Product Ingredients as Inhibitors of Human HMG-CoA Reductase through Structure-Based Virtual Screening. Drug Des. Devel. Ther. 2015, 9, 3313. [PubMed]

21. Young Shin, J.; Young Kim, J.; Tak Kang, H.; Hwa Han, K.; Yong Shim, J. Effect of Fruits and Vegetables on Metabolic Syndrome: A Systematic Review and Meta-Analysis of Randomized Controlled Trials. Int. J. Food Sci. Nutr. 2015, 66, 416-425. [CrossRef] [PubMed]

22. Lee, M.; Lim, M.; Kim, J. Fruit and Vegetable Consumption and the Metabolic Syndrome: A Systematic Review and Dose-Response Meta-Analysis. Br. J. Nutr. 2019, 122, 723-733. [CrossRef] [PubMed]

23. El-Beltagi, H.S.; El-Ansary, A.E.; Mostafa, M.A.; Kamel, T.A.; Safwat, G. Evaluation of the Phytochemical, Antioxidant, Antibacterial and Anticancer Activity of Prunus Domestica Fruit. Not. Bot. Horti Agrobot. Cluj Napoca 2019, 47, 395-404. [CrossRef]

24. Igwe, E.O.; Charlton, K.E. A Systematic Review on the Health Effects of Plums (Prunus domestica and Prunus salicina). Phytother. Res. 2016, 30, 701-731. [CrossRef]

25. Furchner-Evanson, A.; Petrisko, Y.; Howarth, L.; Nemoseck, T.; Kern, M. Type of Snack Influences Satiety Responses in Adult Women. Appetite 2010, 54, 564-569. [CrossRef]

26. Nilsson, A.; Ostman, E.; Holst, J.; Björck, I. Including Indigestible Carbohydrates in the Evening Meal of Healthy Subjects Improves Glucose Tolerance, Lowers Inflammatory Markers, and Increases Satiety after a Subsequent Standardized Breakfast. J. Nutr. 2008, 138, 732-739. [CrossRef]

27. di Matteo, G.; Spano, M.; Esposito, C.; Santarcangelo, C.; Baldi, A.; Daglia, M.; Mannina, L.; Ingallina, C.; Sobolev, A.P. NMR Characterization of Ten Apple Cultivars from the Piedmont Region. Foods 2021, 10, 289. [CrossRef]

28. Ingallina, C.; Spano, M.; Sobolev, A.P.; Esposito, C.; Santarcangelo, C.; Baldi, A.; Daglia, M.; Mannina, L. Characterization of Local Products for Their Industrial Use: The Case of Italian Potato Cultivars Analyzed by Untargeted and Targeted Methodologies. Foods 2020, 9, 1216. [CrossRef]

29. Singleton, V.L.; Rossi, J.A. Colorimetry of Total Phenolics with Phosphomolybdic-Phosphotungstic Acid Reagents. Am. J. Enol. Vitic. 1965, 16, 144-158.

30. Kok, J.M.L.; Jee, J.M.; Chew, L.Y.; Wong, C.L. The Potential of the Brown Seaweed Sargassum Polycystum against Acne Vulgaris. J. Appl. Phycol. 2016, 28, 3127-3133. [CrossRef]

31. Mass Bank of North America. Available online: https:/ / mona.fiehnlab.ucdavis.edu/ (accessed on 18 July 2021).

32. Sirius. Available online: https://bio.informatik.uni-jena.de/software/sirius/ (accessed on 18 July 2021).

33. Cicolari, S.; Dacrema, M.; Tsetegho Sokeng, A.J.; Xiao, J.; Atchan Nwakiban, A.P.; di Giovanni, C.; Santarcangelo, C.; Magni, P.; Daglia, M. Hydromethanolic Extracts from Adansonia digitata L. Edible Parts Positively Modulate Pathophysiological Mechanisms Related to the Metabolic Syndrome. Molecules 2020, 25, 2858. [CrossRef] [PubMed]

34. Nwakiban, A.P.A.; Sokeng, A.J.; Dell'Agli, M.; Bossi, L.; Beretta, G.; Gelmini, F.; Tchamgoue, A.D.; Agbor, G.A.; Kuiaté, J.R.; Daglia, M.; et al. Hydroethanolic Plant Extracts from Cameroon Positively Modulate Enzymes Relevant to Carbohydrate/Lipid Digestion and Cardio-Metabolic Diseases. Food Funct. 2019, 10, 6533-6542. [CrossRef]

35. Galuppo, M.; Rossi, A.; Giacoppo, S.; Pace, S.; Bramanti, P.; Sautebin, L.; Mazzon, E. Use of Mometasone Furoate in Prolonged Treatment of Experimental Spinal Cord Injury in Mice: A Comparative Study of Three Different Glucocorticoids. Pharmacol. Res. 2015, 99, 316-328. [CrossRef] [PubMed]

36. Capitani, D.; Sobolev, A.P.; Delfini, M.; Vista, S.; Antiochia, R.; Proietti, N.; Bubici, S.; Ferrante, G.; Carradori, S.; Salvador, F.R.D.; et al. NMR Methodologies in the Analysis of Blueberries. Electrophoresis 2014, 35, 1615-1626. [CrossRef]

37. Mannina, L.; Sobolev, A.P.; Viel, S. Liquid State 1H High Field NMR in Food Analysis. Prog. Nucl. Magn. Reson. Spectrosc. 2012, 66, 1-39. [CrossRef] [PubMed]

38. Capitani, D.; Mannina, L.; Proietti, N.; Sobolev, A.P.; Tomassini, A.; Miccheli, A.; di Cocco, M.E.; Capuani, G.; de Salvador, R.; Delfini, M. Monitoring of Metabolic Profiling and Water Status of Hayward Kiwifruits by Nuclear Magnetic Resonance. Talanta 2010, 82, 1826-1838. [CrossRef]

39. WHO Hypertension. Available online: https://www.who.int/ne\%0Aws-room/fact-sheets/detail/hypertension (accessed on 23 June 2021).

40. WHO Diabetes. Available online: https://www.who.int/news-roo\%0Am/fact-sheets/detail/diabetes (accessed on 23 June 2021).

41. WHO Obesity and Overweight. Available online: https://www.who.int/news-room/fact-sheets/detail/obesity-and-overweight (accessed on 23 June 2021).

42. Mandlekar, S.; Hong, J.L.; Tony Kong, A.N. Modulation of Metabolic Enzymes by Dietary Phytochemicals: A Review of Mechanisms Underlying Beneficial versus Unfavorable Effects. Curr. Drug Metab. 2006, 7, 661-675. [CrossRef] [PubMed]

43. Ullah, H.; de Filippis, A.; Khan, H.; Xiao, J.; Daglia, M. An Overview of the Health Benefits of Prunus Species with Special Reference to Metabolic Syndrome Risk Factors. Food Chem. Toxicol. 2020, 144, 111574. [CrossRef] [PubMed]

44. Moracci, L.; Traldi, P.; Agostini, M. Mass Spectrometry for a Holistic View of Natural Extracts of Phytotherapeutic Interest. Mass Spectrom. Rev. 2020, 39, 553-573. [CrossRef]

45. Kumar Singla, R.; Singh, R.; Kumar Dubey, A. Important Aspects of Post-Prandial Antidiabetic Drug, Acarbose. Curr. Top. Med. Chem. 2016, 16, 2625-2633. [CrossRef] 
46. Nowicka, P.; Wojdyło, A.; Samoticha, J. Evaluation of Phytochemicals, Antioxidant Capacity, and Antidiabetic Activity of Novel Smoothies from Selected Prunus Fruits. J. Funct. Foods 2016, 25, 397-407. [CrossRef]

47. Wang, T.; Li, X.; Zhou, B.; Li, H.; Zeng, J.; Gao, W. Anti-Diabetic Activity in Type 2 Diabetic Mice and $\alpha$-Glucosidase Inhibitory, Antioxidant and Anti-Inflammatory Potential of Chemically Profiled Pear Peel and Pulp Extracts (Pyrus spp.). J. Funct. Foods 2015, 13, 276-288. [CrossRef]

48. Boath, A.S.; Stewart, D.; McDougall, G.J. Berry Components Inhibit $\alpha$-Glucosidase in Vitro: Synergies between Acarbose and Polyphenols from Black Currant and Rowanberry. Food Chem. 2012, 135, 929-936. [CrossRef] [PubMed]

49. Nor-Liyana, J.; Siroshini, K.T.; Nurul-Syahirah, M.B.; Chang, W.L.; Nurul-Husna, S.; Daryl, J.A.; Khairul-Kamilah, A.K.; Hasnah, B. Phytochemical Analysis of Elateriospermum Tapos and Its Inhibitory Effects on Alpha-Amylase, Alpha-Glucosidase and Pancreatic Lipase. J. Trop. For. Sci. 2019, 31, 240-248.

50. Popović, B.M.; Blagojević, B.; Kucharska, A.Z.; Agić, D.; Magazin, N.; Milović, M.; Serra, A.T. Exploring Fruits from Genus Prunus as a Source of Potential Pharmaceutical Agents-In Vitro and in Silico Study. Food Chem. 2021, 358, 129812. [CrossRef]

51. Catapano, A.L.; Graham, I.; de Backer, G.; Wiklund, O.; Chapman, M.J.; Drexel, H.; Hoes, A.W.; Jennings, C.S.; Landmesser, U.; Pedersen, T.R.; et al. 2016 ESC/EAS Guidelines for the Management of Dyslipidaemias: The Task Force for the Management of Dyslipidaemias of the European Society of Cardiology (ESC) and European Atherosclerosis Society (EAS) Developed with the Special Contribution of the Europea. Atherosclerosis 2016, 253, 281-344. [CrossRef]

52. Susilowati, R.; Jannah, J.; Maghfuroh, Z.; Kusuma, M.T. Antihyperlipidemic Effects of Apple Peel Extract in High-Fat Diet-Induced Hyperlipidemic Rats. J. Adv. Pharm. Technol. Res. 2020, 11, 128. [CrossRef]

53. Baskaran, G.; Salvamani, S.; Ahmad, S.A.; Shaharuddin, N.A.; Pattiram, P.D.; Shukor, M.Y. HMG-CoA Reductase Inhibitory Activity and Phytocomponent Investigation of Basella Alba Leaf Extract as a Treatment for Hypercholesterolemia. Drug Des. Devel. Ther. 2015, 9, 509. [CrossRef]

54. Hartanti, L.; Yonas, S.M.K.; Mustamu, J.J.; Wijaya, S.; Setiawan, H.K.; Soegianto, L. Influence of Extraction Methods of Bay Leaves (Syzygium Polyanthum) on Antioxidant and HMG-CoA Reductase Inhibitory Activity. Heliyon 2019, 5, e01485. [CrossRef] [PubMed]

55. Iqbal, D.; Khan, M.S.; Khan, A.; Khan, M.; Ahmad, S.; Srivastava, A.K.; Bagga, P. In Vitro Screening for $\beta$-Hydroxy- $\beta$ Methylglutaryl-Coa Reductase Inhibitory and Antioxidant Activity of Sequentially Extracted Fractions of Ficus Palmata Forsk. Biomed Res. Int. 2014, 2014, 1-10. [CrossRef]

56. Salvamani, S.; Gunasekaran, B.; Shukor, M.Y.; Shaharuddin, N.A.; Sabullah, M.K.; Ahmad, S.A. Anti-HMG-CoA Reductase, Antioxidant, and Anti-Inflammatory Activities of Amaranthus Viridis Leaf Extract as a Potential Treatment for Hypercholesterolemia. Evid. Based Complement. Alternat. Med. 2016, 2016, 1-10. [CrossRef]

57. Pilitsi, E.; Farr, O.M.; Polyzos, S.A.; Perakakis, N.; Nolen-Doerr, E.; Papathanasiou, A.E.; Mantzoros, C.S. Pharmacotherapy of Obesity: Available Medications and Drugs under Investigation. Metabolism 2019, 92, 170-192. [CrossRef]

58. FDA Orlistat (Marketed as Alli and Xenical) Information. Available online: https://www.fda.gov/drugs/postmarket-drugsafety-information-patients-and-providers/orlistat-marketed-alli-and-xenical-information (accessed on 2 August 2021).

59. FDA FDA Drug Safety Communication: Completed Safety Review of Xenical/Alli (Orlistat) and Severe Liver Injury. Available online: https://www.fda.gov/drugs/postmarket-drug-safety-information-patients-and-providers/fda-drug-safetycommunication-completed-safety-review-xenicalalli-orlistat-and-severe-liver-injury (accessed on 2 August 2021).

60. European Medicines Agency European Medicines Agency Starts Review of Orlistat-Containing Medicines. Available online: https:/ / www.ema.europa.eu/en/news/european-medicines-agency-starts-review-orlistat-containing-medicines (accessed on 2 August 2021).

61. Buchholz, T.; Melzig, M.F. Polyphenolic Compounds as Pancreatic Lipase Inhibitors. Planta Med. 2015, 81, 771-783. [CrossRef] [PubMed]

62. McDougall, G.J.; Stewart, D. The Inhibitory Effects of Berry Polyphenols on Digestive Enzymes. Biofactors 2005, 23, 189-195. [CrossRef] [PubMed]

63. Gholamhoseinian, A.; Shahouzehi, B.; Sharifi-Far, F. Inhibitory Effect of Some Plant Extracts on Pancreatic Lipase. Int. J. Pharmacol. 2010, 6, 18-24. [CrossRef]

64. Jaradat, N.; Zaid, A.N.; Hussein, F.; Zaqzouq, M.; Aljammal, H.; Ayesh, O. Anti-Lipase Potential of the Organic and Aqueous Extracts of Ten Traditional Edible and Medicinal Plants in Palestine; a Comparison Study with Orlistat. Medicines $2017,4,89$. [CrossRef]

65. Nowicka, P.; Wojdyło, A.; Laskowski, P. Inhibitory Potential against Digestive Enzymes Linked to Obesity and Type 2 Diabetes and Content of Bioactive Compounds in 20 Cultivars of the Peach Fruit Grown in Poland. Plant Foods Hum. Nutr. 2018, 73, 314-320. [CrossRef]

66. Welty, F.K.; Alfaddagh, A.; Elajami, T.K. Targeting Inflammation in Metabolic Syndrome. Transl. Res. 2016, 167, 257-280. [CrossRef] [PubMed]

67. Silvan, J.M.; Michalska-Ciechanowska, A.; Martinez-Rodriguez, A.J. Modulation of Antibacterial, Antioxidant, and AntiInflammatory Properties by Drying of Prunus domestica L. Plum Juice Extracts. Microorganisms 2020, 8, 119. [CrossRef]

68. Hooshmand, S.; Kumar, A.; Zhang, J.Y.; Johnson, S.A.; Chai, S.C.; Arjmandi, B.H. Evidence for Anti-Inflammatory and Antioxidative Properties of Dried Plum Polyphenols in Macrophage RAW 264.7 Cells. Food Funct. 2015, 6, 1719-1725. [CrossRef] 
69. Sunil, M.A.; Sunitha, V.S.; Santhakumaran, P.; Mohan, M.C.; Jose, M.S.; Radhakrishnan, E.K.; Mathew, J. Protective Effect of (+)-Catechin against Lipopolysaccharide-Induced Inflammatory Response in RAW 264.7 Cells through Downregulation of NF-KB and P38 MAPK. Inflammopharmacology 2021, 29, 1139-1155. [CrossRef]

70. Lee, S.H.; Lee, S.Y.; Son, D.J.; Lee, H.; Yoo, H.S.; Song, S.; Oh, K.W.; Han, D.C.; Kwon, B.M.; Hong, J.T. Inhibitory Effect of 2'-Hydroxycinnamaldehyde on Nitric Oxide Production through Inhibition of NF-KB Activation in RAW 264.7 Cells. Biochem. Pharmacol. 2005, 69, 791-799. [CrossRef]

71. Zhang, M.; Xie, Y.; Su, X.; Liu, K.; Zhang, Y.; Pang, W.; Wang, J. Inonotus Sanghuang Polyphenols Attenuate Inflammatory Response via Modulating the Crosstalk between Macrophages and Adipocytes. Front. Immunol. 2019, 10, 286. [CrossRef] [PubMed]

72. Overman, A.; Bumrungpert, A.; Kennedy, A.; Martinez, K.; Chuang, C.C.; West, T.; Dawson, B.; Jia, W.; McIntosh, M. PolyphenolRich Grape Powder Extract (GPE) Attenuates Inflammation in Human Macrophages and in Human Adipocytes Exposed to Macrophage-Conditioned Media. Int. J. Obes. 2010, 34, 800-808. [CrossRef] [PubMed]

73. Zielińska-Wasielica, J.; Olejnik, A.; Kowalska, K.; Olkowicz, M.; Dembczyński, R. Elderberry (Sambucus nigra L.) Fruit Extract Alleviates Oxidative Stress, Insulin Resistance, and Inflammation in Hypertrophied 3T3-L1 Adipocytes and Activated RAW 264.7 Macrophages. Foods 2019, 8, 326. [CrossRef] [PubMed]

74. Ekor, M. The Growing Use of Herbal Medicines: Issues Relating to Adverse Reactions and Challenges in Monitoring Safety. Front. Pharmacol. 2014, 4, 177. [CrossRef] 